\title{
The Effect of Board Structure on Egyptian Mutual Fund Performance: A Structural Equation Model Analysis
}

\author{
Nancy Youssef ${ }^{1} \&$ Peng Zhou ${ }^{2}$ \\ ${ }^{1}$ School of Management and Technology, Arab Academy for Science, Technology \& Maritime Transport, Egypt \\ ${ }^{2}$ Cardiff Business School, Cardiff University, UK \\ Correspondence: Nancy Youssef, School of Management and Technology, Arab Academy for Science, Technology \\ \& Maritime Transport, Egypt. Tel: 203-562-2366. E-mail: nancyyoussef@aast.edu
}

Received: January 6, 2020

Accepted: January 28, 2020

Online Published: February 10, 2020

doi:10.5539/ijef.v12n3p1

URL: https://doi.org/10.5539/ijef.v12n3p1

\begin{abstract}
Purpose - This paper empirically explores the causality between board structure and the fund performance in the mutual fund industry of an emerging market.

Design - Using a panel of 82 Egyptian funds spanning 10 years before and after the global financial crisis, we develop a Structural Equation Model to deal with the endogeneity between measures of governance and performance in a systematic and identified way.

Findings - Experimental results show a significant negative relationship between the equity ownership by the directors and the fund performance. Evidence shows little support for a significant effect of board structure on the performance after controlling for the endogeneity. It implies the misconduct of governance rules in Egypt, especially the weakness in board composition.

Originality- Given the important role of mutual fund industry in Egypt, this is the first study of its kind explores the causality between board structure and the fund performance in the mutual fund.
\end{abstract}

Keywords: corporate governance, mutual fund, endogeneity, structural equation model

JEL Classification: G34, G23, C3.

\section{Introduction}

Most studies on the nexus among performance, board structure and ownership structure are based on developed economies. Baysinger and Butler (1985) find that there is a positive relationship between the number of independent directors and performance in major US business corporations. Similarly, Khorana et al. (2007) also confirm this relationship in the US mutual fund industry. They distinguish three components of board composition: the executive component, the monitoring component, and the instrumental component. The executive component provides information and expertise necessary for corporate strategy and business policy. The monitoring component fulfils a policing function over management's performance and represents shareholders' interests. The instrumental component provides general knowledge, networking, and productive links between organizations. They conclude that inside directors provide the executive component; independent directors fulfil the monitoring component. Cochran et al. (1985) provide evidence to support this complementarity between the inside and outside/independent directors. Similarly, Rosenstein and Wyatt (1990) document positive abnormal returns when an outside director is appointed with more positive abnormal returns for impartial and financial outsiders compared to the appointment of corporate outsiders. Brickley et al. (1994) also support the independent director monitoring hypothesis and show that outsider-dominated boards accrue positive performance on the declaration of poison pill defences, among others (Yermack, 1996; Ding \& Wermers, 2012).

However, many studies find that the proportion of outside directors have a negative impact on performance (Agrawal \& Knoeber, 1998; Agrawal \& Knoeber, 1996; Klein, 1998; Bhagat \& Black, 2002). Additionally, other empirical work finds no significant relationship at all (Hermalin \& Weisbach, 1991; Mehran, 1995; Ferris \& Yan 2007). Due to the lack of experi-ence of most of the independent directors, Adams et al. (2009) find that firms that suffer from essential financial problems during the 2008-2009 crisis, had more independent directors than others.

The empirical findings on the effect of board size on firm performance are also mixed. Agrawal and Knoeber 
(1998), Yermack (1996), Eisenberg et al. (1998), Cheng (2008) and Guest (2009) all find a negative relationship, while Belkhir (2009), Ding and Wermers (2012) and Wintoki et al., 2012 find a positive relationship. Barnhart and Rosenstein (1998) show that the board composition, managerial ownership, and performance are endogenous. Brickley and James (1987) argue that there is a negative correlation between managerial consumption of perquisites and both proportion of independent directors and concentration of ownership. Similar conclusions are obtained by Mak and Li (2001). Recent evidence from Kryzanowski and Mohebshahedin (2016) also shows a positive relationship between directors' ownership and CEF returns of US closed-end funds (CEFs) during 19942013, where the generalized method of moments estimator is used to solve the endogeniety problem.

It has been gradually recognised that endogeneity exists widely in many corporate finance models (Agrawal \& Knoeber, 1996; Cremers \& Romano, 2011; Youssef et al., 2017; Sakr et al., 2017). The endogenous relationship between board structure and performance has received a special attention in the empirical literature (Durlauf \& Quah, 1999; Asada et al., 1998; Wintoki et al., 2012). Evidence from developed countries with mature financial institutions shows that firms with stronger shareholder rights had higher firm value, higher profits, higher sales growth, lower capital expenditures, and made fewer corporate acquisitions, because the quality of fund governance is positively correlated to fund performance (Gompers et al., 2003). In particular, Cremers and Romano (2011) use difference-in-differences technique to examine the impact of the mutual fund voting disclosure regulation announced by the SEC in 2003. The endogeneity issue is handled by taking differences to purify the effect of the regime shift. In an earlier paper by Agrawal and Knoeber (1996), the potential endogeneity problem be-tween internal governance measures and performance is addressed by spelling out the agency problem between managers and shareholders. They find that the effect of insider shareholding disappears when the when a simultaneous systems framework is used.

Structural models have gradually gained its popularity in the corporate governance literature. For example, Dalton et al. (1999) builds a structural model to explain board composition. Lin (2005) studies the influences of the board of directors and large external shareholders on CEO compensation. Tam and Tan (2007) examine the relationship between ownership types and firm performance. Zhang (2010) employs a similar tool to examine how corporate boards can create a sustainable competitive advantage. Similar to Cremers and Romano (2011) and Agrawal and Knoeber (1996), the current paper examines the role of corporate governance in mutual fund performance allowing for endogenous board structure and ownership structure. This structural equation model (SEM) approach explicitly spells out the endogeneity among the three key variables, corporate governance, and ownership structure and fund performance. The advantage of the SEM approach over the so-called limited information approach (e.g. 2SLS, GMM, difference-in-differences) is that it is more statistically efficient in data use and it paints a more complete picture of how endogenous variables interact with each other in a sys-tem. More importantly, we provide a better identification strategy by a clearly defined structural model, compared to the reduced-form models which underlie the limited information approach.

In this paper, we attempt to answer four questions by a systematic and structural approach in the context of an emerging market, Egypt:

- What are the determinants for the performance of mutual funds?

- What are the determinants for the board structure of mutual funds?

- What are the determinants for the ownership structure?

- $\quad$ Are these three questions inter-correlated?

The aim of this research is to improve a model to enhance the performance of mutual fund board of directors in the Egyptian Stock Market. To achieve the aim of this research, three research objectives are established. Objective one: to present a comprehensive literature review on mutual fund governance, and how it has become a very important issue for both developed and emerging countries. Objective two: to examine the ability of mutual funds mangers to fulfil excess returns, and build system-based model (SEM) to analyse the mutual causality among endogenous variables. Objective three: to provide a set of recommendations to improve the performance of mutual funds in the Egyptian Stock Market.

The rest of this paper is structured as follows: section 2 reviews the previous literature; section 3 discusses the research gaps section 4 discusses the empirical hypothesis on the relationship between mutual fund board structure and performance; section 5 discusses the research design including the econometric approach and data description; section 6 lays out the structural equation modelling analysis. Finally, section 7 concludes, and it presents research contributions and suggestions for future studies. 


\section{Literature Review}

In corporate governance research, there has been a slow but constant increase in the use of SEM (Dalton et al., 1999; Lin, 2005; Tam \& Tan, 2007; and Zhang, 2010). For example, Dalton et al (1999) uses a structural equation model to measure board composition. Lin (2005) studies the influence of the board of directors and large external shareholders on controlling CEO compensation using SEM. Tam and Tan (2007) examine the relationship between ownership types and firm performance through SEM. Zhang (2010) employs SEM to examine how corporate boards can create a sustainable competitive advantage (Azim, 2012). Similar to Cremers and Romano (2011) and Agrawal and Knoeber (1996), this paper examines the role of corporate governance in mutual fund performance through investigating the effect of the board of directors on mutual fund performance, and the effect of ownership on mutual fund performance which will be illustrated below.

In agency theory, the corporate boards, assuming the power to look after the firm, involve in arm's length transaction with CEO and design such compensation plans which provide CEO with efficient incentives to maximize the shareholder value, and hence reduce moral hazard problem arising from separation of ownership from control. This predicts a positive link between CEO compensation and firm performance (Ibrahim et al., 2019).

Baysinger and Butler (1985) suggest that there is a positive relationship between independent directors and performance. They further view that board composition as providing three components: the executive component, the monitoring component, and the instrumental component. The executive component provides information and expertise necessary for corporate strategy and business policy. The monitoring component fulfils a policing function over management's performance and represents shareholders' interests. The instrumental component provides general knowledge, networking, and productive links between organizations. They conclude that inside directors provide the executive component; independent directors fulfil the monitoring component. Similarly, Khorana et al. (2007) illustrate that independent directors enhance performance.

The results of Cochran et al. (1985) raise doubts about the theory that insider-dominated boards allow managers to consume higher levels of perquisites than do boards having other compositions. Similarly, Rosenstein and Wyatt (1990) document positive abnormal returns when an outside director is appointed with more positive abnormal returns for impartial and financial outsiders compared to the appointment of corporate outsiders.

Brickley et al. (1994) also supports the independent director monitoring hypothesis and shows outside dominated boards accrue positive performance on the declaration of poison pill defences. On the contrary, Agrawal and Knoeber (1998) find that the proportion of outside directors have a negative impact on performance.

Furthermore, (e.g., Agrawal \& Knoeber, 1996; Klein, 1998; Bhagat \& Black, 2002) find a negative relationship between independent directors and firm performance. Additionally, (Hermalin \& Weisbach, 1991; Mehran, 1995; and Ferris \& Yan, 2007) find no relationship at all. On contrary, Yermack (1996), and Ding and Wermers (2012) find a positive relationship. Due to the lack of experience of most of the independent directors, Adams et al. (2009) find that firms that suffer from essential financial problems during the 2008-2009 crisis, had more independent directors than others.

Additionally, (e.g., Agrawal \& Knoeber 1998, Yermack, 1996; Eisenberg et al., 1998; Cheng, 2008; and Guest, 2009) find a negative relationship between firm performance and board size. On contrary, Belkhir (2009) and Ding and Wermers (2012) find a positive relationship between firm performance and board size (Wintoki et al., 2012).

Barnhart and Rosenstein (1998) find that the variables of board composition, managerial ownership, and performance are simultaneously determined. Recent empirical work supports the monitoring hypothesis for board of directors. Brickley and James (1987) find that there is a negative correlation between managerial consumption of perquisites and both proportion of independent directors and concentration of ownership. Similarly, Mak and $\mathrm{Li}$ (2001) find that there is a negative correlation between the proportion of independent directors and both board size and managerial ownership. Recent evidence of Kryzanowski and Mohebshahedin (2016) finds that there is a positive relationship between directors' ownership and CEF returns of U.S. closed-end funds (CEFs) during 19942013, using a dynamic panel two-step system generalized method of moment's estimator to solve the endogeniety problem.

Corporate governance for emerging economies is a topic of vital importance (Patel, 2019). This topic is much important for the emerging economies because they have different dynamics and are closely controlled. So due to this, the research results of developed economies cannot be used for policy development in an emerging economy context. Furthermore, he first Egyptian Code of Corporate Governance (ECCG) was issued in 2005 but lacks complete implementation. 


\section{Research Gaps}

A large body of empirical research on corporate finance suggests that governance structures improve performance, but this research has serious issues with endogeneity (Wintoki et al., 2012). However, the implications for the empirical work will be usefulness if it does not deal with endogeneity problem, because the results will be biased and cannot be dependable (Roberts \& Whited, 2012).

Consequently, when this research investigates the role of corporate governance mechanisms on performance, endogeneity come from the powerful association between past values of the regressand (performance), and current values of the regressors (corporate governance structure) (Wintoki et al., 2012; Agrawal \& Knoeber, 1996; Rediker \& Seth, 1995; Chandio, 2011; Klein \& Zur, 2011; Westland, 2010; Rundle-Thiele et al., 2008; Cornett et al., 2007; Hair et al., 2006). There are many methods of overcoming this; including Maximum likelihood (ML) and Ggeneralized Method of Moments (GMM).

The first method (2SLS/3SLS) requires finding an Instrumental Variable (IV). The solution to such problem is to change the way we estimate $\beta$ to make it identifiable. For this, we should have an "instrument", a variable which we can refer to as $\mathrm{z}$. There are two conditions that should be satisfied about $\mathrm{z}$ to consider it a valid instrument:

1) $z$ must be uncorrelated with $\varepsilon: \mathrm{E}(\varepsilon \mathrm{z})=0$.

2) $\mathrm{z}$ must be correlated to $\mathrm{x}$, and preferably, this correlation will be as high as possible: $\mathrm{E}(\mathrm{z} \mathrm{x}) \neq 0$.

We can use lagged variable as (IV). Thus, $\mathrm{X} 1 \mathrm{t}$ is a current (present-time) exogenous variable, while $\mathrm{X} 1(\mathrm{t}-1)$ is a lagged exogenous variable, with a lag of one time period. Additionally, (3SLS) method requires three steps: firststage regressions to get predicted values for the endogenous regressors; a (2SLS) step to get residuals to estimate the cross-equation correlation matrix; and the final 3SLS estimation step. (2SLS/3SLS) is a Limited Information Maximum Likelihood (LIML) which estimates a single structural equation at a time.

Although, GMM and ML is a general framework for deriving estimators, there is a difference between the assumptions of the two methods. ML estimators use assumptions about the specific families of distributions for the random variables to derive an objective function. '; 8It selects the parameters that are probably have generated the observed data, which can be proceeded by maximizing an objective function. GMM estimators use assumptions about the moments of the random variables to derive an objective function. The assumed moments of the random variables present population moment conditions, which can be achieved by minimizing an objective function. Accordingly, ML can be more efficient than GMM, because ML uses the entire distribution instead of uses specified moments only (Breitung \& Lechner, 1995).

The second method is (SEM) which is a multivariate technique that allows us to estimate a system of equations. Structural Equation Models are often drawn as Path Diagrams. Different likelihood values can be obtained when fitting the same model with SEM and GSEM because the normality of observed exogenous variables is never assumed with GSEM. SEM is a Full Information Maximum Likelihood (FIML) which estimates all the equations and all the unknown parameters jointly.

A variety of corporate governance mechanisms has been previously investigated by using various analytical techniques except SEM (e.g. Boo \& Sharma, 2008; Coles et al., 2001; Fernández \& Arrondo, 2005; and Ward et al., 2009). Therefore, the existence of endogeneity is the enormous restriction of these studies (Schultz et al., 2010). Therefore, to achieve the research objectives empirically, this paper depends on Structural Equation Modeling (SEM) which is a stringent statistical technique to solve the endogeneity problem (Hox \& Bechger, 1998; Azim, 2012). Furthermore, SEM is a Full Information Maximum Likelihood (FIML) that estimates all the equations and all the unknown parameters jointly and obtains robust findings compared with (2SLS/3SLS) which is a Limited Information Maximum Likelihood (LIML) that estimates a single structural equation at a time.

Therefore, this paper utilizes SEM which is a multivariate technique that allows us to estimate a system of equations. Structural Equation Models are often drawn as Path Diagrams. SEM is a Full Information Maximum Likelihood (FIML), which estimates all the equations and all the unknown parameters jointly and obtains robust findings, compared with GMM.

\section{Research Hypotheses}

This paper expands the existing fund governance literature by exploring the impact of the board of directors on mutual fund performance. The objective aim of this study is to improve a model to enhance the performance of mutual fund board of directors in the Egyptian Stock Market. In particular, to examine the ability of mutual funds mangers to fulfil excess returns using system-based model (SEM).

Board size: Lipton and Lorsch (1992), Jensen (1993), Cheng (2008), and Yermack (1996) find that there is negative 
correlation between board size and performance, because larger board of directors needs more settlements to avoid conflicts, which might lead to harm firm value. Similarly, Conyon and Peck (1998) argue that board size has negative impact on firm performance in a number of European firms. Eisenberg et al. (1998) and Guest (2009) suggest that there is a significant inverse relationship between board size and profitability, because poor communication might lead to difficulty in decision-making process which restricts the influence of large board of directors. In contrast, Belkhir (2009) finds that there is a positive association between board size and performance in banking sector; this might be due to that board of directors has the ability to get rid of the poor performing managers. Similarly, Dalton et al. (1999) finds a positive correlation between board size and performance.

\section{H1: There is a positive relationship between board size and fund performance (Perf $\left.f_{i t}\right)$.}

Proportion of independent directors and inside directors: the two ways inside outside director classification is used to measure the proportion of inside directors on the board, and the proportion of outside directors on the board. Ding and Wermers (2012) demonstrate that independent directors have a significant influence on pre-expense performance. In contrast, Ferris and Yan (2007) utilize a large sample of mutual fund families for 2002. They argue that there is no relationship between proportion of independent directors and fund performance

H2: There is a positive relationship between the proportion of independent directors on the board and fund performance (Perfit).

Fama (1980), Chau and Leung (2006), and Weir and Laing (2003) suggest that boards with a higher proportion of independent directors will increase the quality of monitoring over management because "they are not affiliated with the company as officers or employees, and thus are independent representatives of the shareholders' interests" (Pincus et al., 1989). On the other hand, Eng and Mak (2003), Barako et al. (2006), and Gul and Leung (2004) report a significant negative association between the level of voluntary disclosure and board independence. AlMoataz and Hussainey (2013) also find a negative association between corporate governance, voluntary disclosures and board independence in Saudi Arabia, and therefore leads to a lower level of CG Index.

H3: There is a negative relationship between the proportion of independent directors on the board and corporate governance index (CGQ) of the fund management company.

Board committee structure: to examine the role of board committee structure on the performance of mutual funds, this paper focuses on investment committees and audit committees. Similar to Chan et al. (2013) and Lassoued and Elmir (2012), the proportion of directors on the audit committee and the proportion of directors on the investment committee are included in the regression analysis. Furthermore, Klein (1998) finds a positive correlation between the percentage of inside directors on investment committees and stock returns. This result is consistent with Fama and Jensen's (1983) argument that inside director presents prominent knowledge helping the board of directors to make the right investment decisions in the long-term strategy. Similarly, Lam and Lee (2012) find that there is a positive correlation between nomination committee and performance. Although, in this paper there is not any significant relationship neither between the proportion of directors in the investment committee and fund performance (measured by Absolute return, Sharpe ratio and Treynor ratio), nor between the proportion of directors in the audit committee and fund performance (measured by Absolute return, Sharpe ratio and Treynor ratio), the results are consistent with Dowers (1997) argument that investment committee and audit committee are not statistically significantly related to the fund return.

Empirical evidence suggests that audit committees which consist of non-executive directors play a complementary role to information disclosure to decrease agency costs (Forker, 1992; Barako et al, 2006 Fama, 1980; Collier, 1993). Samaha and Dahawy (2010 and 2011, in press) found an audit committee existence complementary effect on the general corporate voluntary disclosures in Egypt; and therefore leads to a higher level of CG Index (Samaha et al, 2012).

H4: There is a positive relationship between the proportion of directors on the audit committee and corporate governance index (CGQ) of the fund management company.

Equity ownership by directors: Morck et al (1988) examine the effect of managerial ownership on firm value, as measured by Tobin's $Q$. They find that there is a positive correlation between managerial ownership and firm value. Short and Keasey (1999) demonstrate that at higher levels of managerial ownership, firms in UK achieve better. Similarly, Mehran (1995) argues that that there is a positive correlation between the proportion of equity held by managers and firm performance. Similar to Ferris and Yan (2007), equity ownership by each director is reported within one of five EGP ranges. The proportion of directors holding zero shares are used as the empirical measure of equity ownership by directors rather than the proportion of directors holding more than EGP 100,000 (or any other EGP range), because holding zero shares of the funds are highly revealing of the absence of any incentive 
for the fund directors.

H5: There is a negative relationship between the equity ownership by the directors (Dir ${ }_{\text {Own }}$ ) and fund performance $\left(\right.$ Perf $\left.f_{i t}\right)$.

H6: There is a positive relationship between the equity ownership by the directors (Dir $\left.{ }_{O w n}\right)$ and the corporate governance index (CGQ) of the fund management company.

Corporate governance index: Similar to Erkens et al (2012), the influence of corporate governance on firm performance is explored. A governance index is constructed - calculated as an average of six governance indicators - using the annual reports of the companies and the companies' websites - based on the OECD Corporate Governance Principles April 2004 (EFSA).

H7: There is a positive relationship between the corporate governance index (CGQ) of the fund management company and fund performance $\left(\operatorname{Perf}_{i t}\right)$.

Erkens et al. (2012) find that powerful mutual fund governance is positively correlated to mutual fund performance. Similar to Kaufmann et al. (2009), a governance index is constructed - calculated as an average of six indicators of governance quality- using the annual reports of the companies and the companies' websites, based on the OECD Corporate Governance Principles April 2004 (EFSA), as illustrated below:

1) Effective Corporate Governance Framework: the corporate governance framework should promote transparent and efficient markets, be consistent with the rule of law and clearly determine the responsibilities among different supervisory, regulatory and enforcement authorities.

2) The rights of shareholders: the corporate governance framework should protect and facilitate the exercise of shareholders' rights.

3) The equitable treatment of shareholders: the corporate governance framework should ensure the equitable treatment of all shareholders, including minority and foreign shareholders.

4) The role of stakeholders in corporate governance: the corporate governance framework should recognize the rights of stakeholders established by law or through mutual agreements and encourage active cooperation between corporations and stakeholders in creating wealth, and the sustainability of financially sound enterprises.

5) Disclosure and transparency: the corporate governance framework should ensure that timely and accurate disclosure is made on all material matters regarding the corporation, including the financial situation, performance, ownership, and governance of the company.

6) The responsibilities of the board: the corporate governance framework should ensure the strategic guidance of the company, the effective monitoring of management by the board, and the board's accountability to the company and the shareholders.

A series of dummy variables is included to describe each of the six components of the corporate governance index of each company represented in the sample to take a value of 1 to indicate the presence of each governance indicator, and zero to indicate the absence of each governance indicator.

We assume that we can write the score of each company for each of the six components of governance index as follows:

$$
\begin{gathered}
C G Q_{i}=\text { Framework }+ \text { Shareholders Rights }+ \text { Shareholders Treatment }+ \text { Stakeholders Role } \\
+ \text { Disclosure }+ \text { Board Responsibilties }
\end{gathered}
$$

$$
C G Q_{i t}=\frac{1}{n} \sum_{i=1}^{n} C G Q_{i}
$$

where:

$C G Q_{i t}$ : the average corporate governance score for company $i$ at time $t$;

$C G Q_{i}$ is the total corporate governance score for company $i$, and $n$ is the number of governance indicators (six) included in the corporate governance index.

The following discussion contains a brief description of the control variables.

Time: the period of the study is the years between 2004 and 2013 due to data availability that can affect the performance of the fund. Jones (2007) suggests that investors who wish to maximize return should start their search by looking for younger funds. Similarly, Aggarwal and Jorion (2010) find strong evidence of out-performance of 
hedge funds during the first two to three years of existence. Based upon the previous discussion, there is a negative relationship between the fund age - which increases over time - and fund performance. Accordingly, there is a negative relationship between the time and fund performance.

Investment objective dummy variables: the type of investment objective a fund adopts affects the risk of a fund's investment portfolio and the return that the fund earns (Williamson, 1972). Similar to Ferris and Yan (2007), Tufano, and Sevick (1997), a series of dummy variables is included to capture the investment objectives represented in the sample to take a value of 1 if the fund belongs to the same category under study and zero otherwise. The investment objectives represented in the sample are: Fund Obj1: Open End Fixed Income Fund, Fund Obj2: Open End Equity Fund, Fund Obj3: Open End Balanced Fund, Fund Obj4: Open End Islamic Fund Obj 5: Open End Money Market Fund, and Fund Obj 6: Others.

Standard Deviation of the Stock Return: Agrawal and Knoeber (1996) include standard deviation of the mutual fund return in their analysis as one of the indicators of the cost arises from holding undiversified portfolio, and they find a negative relationship between the standard deviation of the stock return and the percentage of shares owned by directors. Similar to them, the standard deviation of the mutual fund return is included on model (A) only to control for the total risk, because Perfl (Absolute Performance) is not a risk-adjusted measure like the other two models. Finally, the following Table 1 summarizes the key studies in the previous literature that investigate the effect of board structure on funds' performance.

\section{Research Design}

\subsection{The Data}

The simple random sample for the study is nearly the entire population existing between 2004 and 2013, which are 82 mutual funds due to data availability. The sample is free from survivorship bias, since the sample includes both surviving and dead funds.

\subsection{Endogenous and Exogenous Variables Measurements}

This study uses different endogenous variables, exogenous variables, and control variables which might influence the fund performance (Huber \& Mellace, 2013). The endogenous variables in this study are the financial performance of mutual funds in the Egyptian Stock Market, corporate governance index, and director ownership. The empirical analysis is carried out at different levels: firstly, an absolute performance analysis is presented before risk adjusted performance analysis ratios such as Treynor and Sharpe's are carried out.

Therefore, a mutual fund with large Treynor ratio and low Sharpe ratio indicates that it has a relatively larger unsystematic risk (Bodie et al., 2007). See, Table 2 providing a full set of variables of the study (Huber \& Mellace, 2013).

Similar to Agrawal and Knoeber (1996), the standard deviation of the mutual fund return is included on model (A) only to control for the total risk, because Perf1 (Absolute Performance) is not a risk-adjusted measure like the other two models. Finally, the following Table 1 summarizes the key studies in the previous literature that investigate the effect of board structure on funds' performance.

\subsection{Description of Sample Characteristics}

This section presents descriptive statistics regarding board structure and fund perfor-mance. Table 3 includes four panels; Panel A: Fund and Governance Descriptive Sta-tistics for the three models (A), (B), and (C), Panel B: Pearson Correlations for model (A), Panel C: Pearson Correlations for model (B), and Panel D: Pearson Correlations for model (C) which will be illustrated below. The results are based on a sample of 932 annual and semi-annual observations for 82 mutual funds from 2004 to 2013.

\section{1). Panel A: Fund and Governance Descriptive Statistics}

Panel A provides fund and corporate governance statistics for the overall sample. Perf1, Perf2, and Perf3for the overall sample, have mean values of, $0.16 \%,-49 \%$, and $-15 \%$, respectively. Their mean values, however, vary somewhat more with perf2 having lower mean value than Perf1 (about 49.16\%), and perf3 having lower mean value than Perf1 (about $15.16 \%$ ). These differences in the mean values are driven by the divergence between Treynor ratio (Perf3), Sharpe ratio (Perf2), and the Absolute performance (Perf1) in ranking investment portfolios. Although both the Treynor ratio and Sharpe ratio are used as risk-adjusted measure to rank investment portfolios, Treynor's compensates for the systematic risk only, while the Sharpe ratio compen-sates for the total risk, comprising both systematic and unsystematic risk.

For the overall sample, on average, the board structure is comprised of eight directors, and about $80 \%$ of them are independent directors. The board composition, on average, consists of $27 \%$ of directors on the audit committee, 
and $18 \%$ of directors on the in-vestment committee. The board of directors, on average, includes $34 \%$ financial direc-tors, and $41 \%$ professional directors. The average tenure of directors is 19 years. In terms of director ownership, about $84 \%$ of directors hold zero shares. Furthermore, the corporate governance index, on average, is $58 \%$. The number of funds overseen by the fund management company, on average, is nine mutual funds. Furthermore, the major funds in the sample belong to open end equity fund.

2). Panel B: Pearson Correlations (Model A)

Panel B provides the correlations between all variables included in model (A). Inter-estingly, the correlations for BSize, and IndDir is positive for DirOwn suggesting that vigilant boards are associated with a high fraction of directors holding zero shares. Furthermore, the correlations for Perf1, BSize, AudComm, DirOwn, DirFn, FinDir, and ProfDir are positive for CGQ suggesting that vigilant boards are associated with a higher corporate governance index. Additionally, the correlations for AudComm, InvComm, and CGQ are positive for Perf1 suggesting that vigilant boards are associ-ated with a higher performance.

\section{3). Panel C: Pearson Correlations (Model B)}

Panel C provides the correlations between all variables included in model (B). As in-dicated before in model (A), the correlations for BSize and IndDir are positive for DirOwn. Furthermore, the correlations for BSize, AudComm, DirOwn, DirFn, FinDir, and ProfDir are positive for CGQ. Additionally, the correlations for AudCommm and DirTn are positive for Perf2 suggesting that vigilant boards are associated with a high-er performance.

\section{4). Panel D: Pearson Correlations (Model C)}

Panel D provides the correlations between all variables included in model (C). As in-dicated previously in model (A) and model (B), the correlations for BSize and IndDir are positive for DirOwn. Furthermore, the correlations for BSize, AudComm, DirOwn, DirFn, FinDir, and ProfDir are positive for CGQ. Additionally, the correlation for IndDir is positive for Perf3 suggesting that vigilant boards are associated with a high-er performance. Overall, the results are consistent with agency theory literatures sug-gest that firm good governance characteristics, including an independent and vigilant board, will enhance firm performance (Essen et al., 2013).

\section{Empirical Evidence}

To test the effect of board composition on mutual fund performance, this paper utilizes SEM technique to deal with the endogeniety problem through the following three stages model specification, model estimation, and goodness of fit indices (Hair et al., 2006).

\subsection{Structural Model Specification}

To establish the model for fund performance, we base our specification on Erkens et al. (2012) who argue that powerful mutual fund governance is positively correlated to mutual fund performance and on Short and Keasey (1999) and Mehran (1995) who argue that that there is a positive correlation between the proportion of equity held by managers and firm performance. These two hypotheses are derived from literature on the developed economies, so we expect to see some different patterns in the context of an emerging market like Egypt. The first equation of the SEM can be modelled by the following specification:

$$
\begin{gathered}
\operatorname{Perf}_{i t}=\alpha_{i t}+\alpha_{1}\left(B_{\text {Size }}\right)+\alpha_{2}\left(\text { Ind }_{\text {Dir }}\right)+\alpha_{3}\left(\text { Fin }_{\text {Dir }}\right)+\alpha_{4}\left(\text { Prof }_{\text {Dir }}\right)+\alpha_{5}\left(\text { Dir }_{T n}\right)+\alpha_{6}(\text { CGQ }) \\
+\alpha_{7}\left(\text { Dir }_{O w n}\right)+\alpha_{8}\left(\text { Inv }_{\text {Comm }}\right)+\alpha_{9}\left(\text { Aud }_{\text {Comm }}\right)+\alpha_{10}\left(\text { Dir }_{F n}\right)+\alpha_{11}\left(\sigma_{\mathrm{i}}\right)+\alpha_{12}(\text { Time })+\alpha_{13}\left(\text { Dum }_{p}\right) \\
+\alpha_{14}\left(\text { Fund }_{O b j 1}\right)+\alpha_{15}\left(\text { Fund }_{O b j 2}\right)+\alpha_{16}\left(\text { Fund }_{O b j 3}\right)+\alpha_{17}\left(\text { Fund }_{O b j 4}\right)+\alpha_{18}\left(\text { Fund }_{O b j 5}\right)+\varepsilon_{1}
\end{gathered}
$$

Next, the corporate governance quality is assumed to be endogenous with a recursive dependence on the equity ownership by the directors, among other controls:

$$
\begin{gathered}
C G Q=\beta_{i t}+\beta_{1}\left(B_{\text {Size }}\right)+\beta_{2}\left(\operatorname{Ind}_{\text {Dir }}\right)+\beta_{3}\left(\text { Fin }_{\text {Dir }}\right)+\beta_{4}\left(\operatorname{Prof}_{\text {Dir }}\right)+\beta_{5}\left(\operatorname{Dir}_{T n}\right)+\beta_{6}\left(\text { Dir }_{\text {own }}\right)+ \\
\beta_{7}\left(\text { Inv }_{\text {Comm }}\right)+\beta_{8}\left(\text { Aud }_{\text {Comm }}\right)+\beta_{9}\left(\text { Dir }_{F n}\right)+\beta_{10}\left(\text { Fund }_{\text {obj } 1}\right)+\beta_{11}\left(\text { Fund }_{\text {obj } 2}\right)+\beta_{12}\left(\text { Fund }_{\text {obj } 3}\right) \\
+\beta_{13}\left(\text { Fund }_{\text {obj }}\right)+\beta_{14}\left(\text { Fund }_{\text {Obj5 } 5}\right)+\varepsilon_{2}
\end{gathered}
$$

Lastly, the determination of ownership structure is also endogenized using the following specification following the literature on ownership structure:

$$
\begin{gathered}
\operatorname{Dir}_{O w n}=\gamma_{i t}+\gamma_{1}\left(B_{\text {Size }}\right)+\gamma_{2}\left(\operatorname{Ind}_{\text {Dir }}\right)+\gamma_{3}\left(\text { Fin }_{\text {Dir }}\right)+\gamma_{4}\left(\text { Prof }_{D i r}\right)+\gamma_{5}\left(\operatorname{Dir}_{T n}\right)+\gamma_{6}\left(\text { Dir }_{F n}\right) \\
+\gamma_{7}\left(\text { Inv }_{\text {Comm }}\right)+\gamma_{8}\left(\text { Aud }_{\text {Comm }}\right)+\gamma_{9}\left(\text { Fund }_{O b j 1}\right)+\gamma_{10}\left(\text { Fund }_{O b j 2}\right)+\gamma_{11}\left(\text { Fund }_{\text {Obj } 3}\right) \\
+\gamma_{12}\left(\text { Fund }_{O b j 4}\right)+\gamma_{13}\left(\text { Fund }_{O b j 5}\right)+\varepsilon_{3}
\end{gathered}
$$

Since there are three different measures of performances (Perf1, Perf2 and Perf3), we end up with three estimates. 
The model using Perf1 (absolute performance), Perf2 (Sharpe ratio) and Perf3 (Treynor ratio) are respectively named as Model 1, Model 2 and Model 3. The detailed estimation results of the three models are reported in Table 4 , and we illustrate the path diagram of the three endogenous variables in Figure 1.

The differences in the significance levels between the three models are driven by thedivergence between Treynor ratio (Perf3), Sharpe ratio (Perf2), and the absolute per-formance (Perf1) -which are presented before risk adjusted performance analysis ratios such as Treynor and Sharpe's that are carried out - in ranking investment portfolios.

Furthermore, the major limitation of the Treynor Index is that it can be utilized to the schemes with positive betas which indicate a positive correlation with the market movement. The results will mislead if applied to the schemes with negative betas which indicate an inverse relationship with the market movement. In model (C), there are about 173 observations with negative betas, and due to the previous limitation of Treynor Ratio, results are misleading when applied to the schemes with negative betas. Therefore, in model (C) - Perf3 measured by Treynor Ratio - and unlike the previous two models, there is only one estimated coefficient for the path Fund Obj5 $\rightarrow$ Perf3 which is statistically significant and all other estimated coefficients are insignificant.

\subsection{The Estimation Results}

The results about the estimation of the structural model (A), (B), and (C) are presented in Table 4.

According to the previous, in testing the hypotheses, results reveal that there are eleven hypotheses in this study, and ten hypotheses i.e. H1, H2, H3, H4, H5, and H6 are statistically significant. Thus, these hypotheses are supported. While, one hypothesis i.e. H7 is found statistically not significant. Hence, this hypothesis is not supported.

Although the hypothesis is not supported, the result is consistent with Ebaid (2011) argument that the internal audit function in Egypt suffers from many weaknesses that affect negatively its effective role in corporate governance. First, internal audit in Egyptian firms does not enjoy a considerable level of organizational independence or management support, and it does not have the adequate level of qualification necessary to fulfill their new responsibilities.

Second, the internal audit function in the Egyptian firms still focuses on the tradition-al role pertaining to traditional financial audit and has not shifted to the new expand-ed role, whereas internal audit added value to the organization through providing as-surance and consulting activities pertaining to monitoring, evaluating, and improving risk management, control, and governance process. Finally, there is a weak level of interaction between internal and external audit in Egyptian firm.

Furthermore, the result is consistent with Fawzy (2003) argument that however corpo-rate governance standards in Egypt have improved significantly, as reflected in the overall assessment of all five OECD principles, the degree of progress is still far from properly implementing corporate governance principles.

\subsection{The Direct, Indirect and Total Effects}

Table 5 demonstrates direct, indirect, and total effects among all variables in the Structural Equation Model. It includes three panels (A), (B), and (C) respectively.

Panel A: The Effect of Board Structure on Mutual Fund Performance

Panel (A) demonstrates several significant direct, indirect, and total effects. Firstly, DirOwn, ProfDir, BSize, FinDir, and IndDir have significant direct influence on Perf2. Secondly, DirOwn, BSize, and IndDir have significant indirect influence on Perf2 through the mediating effect of CGQ (DirOwn $\rightarrow$ CGQPerf2, BSize $\rightarrow$ $\mathrm{CGQ} \rightarrow$ Perf2, IndDir $\rightarrow$ CGQ $\rightarrow$ Perf2). Finally, DirOwn, ProfDir, and FinDir have significant total influence on Perf2. The Structural Equation Model indicates that evaluation of total effects on the determination of Perf2, arising from the combination of direct and indirect effects of the variables in the model.

Panel B: The Effect of Board Structure on Corporate Governance Index

Panel (B) demonstrates several significant direct, indirect, and total effects. Firstly, DirOwn, DirTn, ProfDir, AudComm, BSize, DirFn, FinDir, and IndDir have a significant direct influence on CGQ. Secondly, ProfDir, BSize, DirFn, FinDir, and IndDir have a significant indirect influence on CGQ through the mediating effect of DirOwn (ProfDir $\rightarrow$ DirOwn $\rightarrow$ CGQ, BSize $\rightarrow$ DirOwn $\rightarrow$ CGQ, DirFn $\rightarrow$ DirOwn $\rightarrow$ CGQ, FinDir $\rightarrow$ DirOwn $\rightarrow$ CGQ, IndDir $\rightarrow$ DirOwn $\rightarrow$ CGQ). Finally, DirOwn, DirTn, ProfDir, AudComm, BSize, DirFn, FinDir, and IndDir have a significant total influence on CGQ.

Panel C: The Effect of Board Structure on Ownership Structure

Panel (C) demonstrates several significant direct and total effects. Firstly, ProfDir, BSize, DirFn, FinDir, and 
IndDir have a significant direct influence on DirOwn. Finally, ProfDir, BSize, DirFn, FinDir, and IndDir have a significant total direct influence on DirOwn. The Structural Equation Model indicates the evaluation of total effects on the determination of DirOwn arising from the direct effects of the variables in the model only because there are no indirect effects of the variables in this model.

\subsection{The Goodness of Fit}

The fit indices shown in Table 6 indicate that the hypothesized structural model provides a good fit to the data. The fit indices indicate that the hypothesized structural model provides a good fit to the data. Firstly, the Likelihood Ratio Chi-squared Test (model vs. saturated) is insignificant for the three models showing that there is no significant difference between the model and saturated model - assuming that all varia-bles are correlated - and therefore, indicating a good fit of the model. The Likelihood Ratio Chi-squared Test (baseline vs. saturated) is significant for the three models showing that there is a strong significant difference between saturated model and baseline model - assuming that no variables are correlated except for exogenous varia-bles when endogenous variables are present - and therefore indicating a good fit of the model.

Secondly, Population error measure, i.e. RMSEA is $0.010,0.021,0.021$ for the three models respectively, indicates a good fit of model because RMSEA $<0.05$. Thirdly, Information criteria measure, i.e. AIC and BIC, indicate that model (A) with the low-est AIC and BIC absolute value 1904.801, 1658.097 respectively fits the data better than the other two models with the larger AIC and BIC value. Fourthly, Baseline comparison measure, i.e. CFI is 1.000, 1.000 , and 1.000 for the three models respec-tively, and TLI is $0.999,0.995$, and 0.994 for the three models respectively, indicates a good fit of model because CFI $>0.95$, and TLI $>0.95$. Finally, Size of residuals measure, i.e. SRMR is $0.002,0.002$, and 0.002 for the three models respectively, and CD is $0.979,0.988$, and 0.975 for the three models respectively, indicates a good fit of model because SRMR $<0.08$, and CD values closer to 1 .

In Table 7 the (R-squared) value of Perf3 (measured by Treynor ratio) is 0.01 and is considered low. This might be due to the major limitation of the Treynor ratio that the results will mislead if applied to the schemes with negative betas, and in model $(\mathrm{C})$, there are 173 observations with negative betas.

\section{Conclusion}

Achieving the aim of this study contributes to the finance literature at three levels, theoretical, methodological and empirical levels. At the theoretical level, firstly, this study bridges the gap between different disciplines including financial performance, mutual fund industry, and corporate governance. Unlike previous studies (Morck et al., 1988; Klein, 1998; Eisenberg et al., 1998), the theoretical model provides insights into the interrelations between board structure, and ownership structure as fundamental determinants of mutual fund performance rather than investigating the effect of each of these mechanisms separately. Secondly, by studying the relationship between board structure and investor welfare, this study indirectly examines the effect of the regulatory requirement.

At the methodological level, unlike previous studies that have addressed that the relationship between board characteristics and firm performance may be spurious because they are endogenously determined and use OLS, 2SLS, 3SLS to overcoming this problem (Erkens et al., 2012; Hermalin \& Weisbach, 2001; Coles et al., 2008; Bhagat \& Black, 2002), this study has achieved the broad objective of developing sophisticated statistical technique of multivariate data analysis (SEM) using STATA (MP v.13). The sample size is large enough to distinguish between different fund performance measures and provide possible differences in the results due to using different measures.

At the empirical level, this study is undertaken in Egypt, and provides evidence from the emerging markets which differ significantly from the developing markets (Farooque et al., 2007). Finally, the study provides evidence against the argument that corporate governance has a significant impact on performance in Egypt, at the level of the mutual funds. However, the study provides evidence of a positive association between independent directors and performance, and a positive association between equity ownership by directors and performance. The findings suggest that governance rules are included in the Egypt Code of Corporate Governance: Guidelines and Standards are not mandatory and lack legislative force (Sharma et al., 2008).

For future research, the model in this study could be expanded to include more factors such as director compensation, because there is no data available for complex-level director compensation in the Egyptian mutual funds. Thus, this paper suggests that the Egyptian Stock Market should require funds to disclose the total director compensation by the complex rather than per fund. The availability of time series data on director compensation by the complex leads to higher quality compensation data for research on the relationship between compensation and performance.

This paper conclude that most of the hypothesized relationships are supported (e.g. BSize is positively associated 
with Perf2 and CGQ, IndDir is positively associated with Perf2 and negatively associated with CGQ, ProfDir is positively associated with Perf2 and negatively associated with DirOwn, AudComm is positively associated with CGQ, DirOwn is negatively associated with Perf2, DirFn is negatively associated with Perf2, and DirTn is negatively associated with CGQ). One is not supported (e.g., CGQ is not associated with Perf1, Perf2, and Perf3).

Additionally, this paper is consistent with (Kryzanowski \& Mohebshahedin, 2016) argument that that there is a positive relationship between ownership by directors and CEF returns (closed-end funds).

The main conclusion of this paper is to provide evidence through robust statistical analysis around the usefulness of governance attributes Egyptian mutual funds ${ }^{\text {ee }}$ performance. The paper finds no evidence on a significant relation between the corporate governance index of the fund management company and fund performance measured by Absolute performance, Sharpe ratio, and Treynor ratio.

Therefore, this paper is consistent with Kirkpatrick (2009) argument that the contribution of effective board oversight and robust risk management including reference to widely accepted standards is not limited to financial institutions. It is also an important, but often neglected, governance aspect in nonfinancial companies. Potential weaknesses in board composition have been obvious for some time and widely debated. The remuneration of boards and senior management also remains a highly controversial issue in many OECD countries.

\section{Acknowledgements}

I would like to express our deepest gratitude to the editors for their time, valuable comments and kind support. I am also grateful for all the research support from AAST (Egypt), Cardiff Metropolitan University and Cardiff University.

\section{References}

Aggarwal, R. K., \& Jorion, P. (2010). The performance of emerging hedge funds and managers. Journal of Financial Economics, 96(2), 238-256. https://doi.org/10.1016/j.jineco.2009.12.010

Agrawal, A., \& Knoeber, C. R. (1996). Firm performance and mechanisms to control agency problems between managers and shareholders. Journal of Financial and Quantitative Analysis, 31(03), 377-397. https://doi.org/10.2307/2331397

Al Farooque, O., Van Zijl, T., Dunstan, K., \& Karim, A. K. M. (2007). Corporate governance in Bangladesh: Link between ownership and financial performance. Corporate Governance: An International Review, 15(6), 1453-1468. https://doi.org/10.1111/j.1467-8683.2007.00657.x

Al-Moataz, E., \& Hussainey, K. (2013). Determinants of corporate governance disclosure in Saudi corporations. Journal of King Abdulaziz University: Economics \& Administration, 27(2). https://doi.org/10.4197/Eco.272.8

Asada, T., Semmler, W., \& Novak, A. J. (1998). Endogenous growth and the balanced growth equilibrium. Research in Economics, 52(2), 189-212. https://doi.org/10.1006/reec.1998.0163

Azim, M. I. (2012). Corporate governance mechanisms and their impact on company performance: A structural equation model analysis. Australian Journal of Management. https://doi.org/10.1177/0312896212451032

Barako, D. G., Hancock, P., \& Izan, H. Y. (2006). Factors influencing voluntary corporate disclosure by Kenyan companies. Corporate Governance: An International Review, 14(2), 107-125. https://doi.org/10.1111/j.14678683.2006.00491.x

Barnhart, S. W., \& Rosenstein, S. (1998). Board composition, managerial ownership, and firm performance: An empirical analysis. Financial Review, 33(4), 1-16. https://doi.org/10.1111/j.1540-6288.1998.tb01393.x

Baysinger, B. D., \& Butler, H. N. (1985). Corporate governance and the board of directors: Performance effects of changes in board composition. Journal of Law, Economics, \& Organization, 1(1), 101-124.

Belkhir, M. (2009). Board of directors' size and performance in the banking industry. International Journal of Managerial Finance, 5(2), 201-221. https://doi.org/10.1108/17439130910947903

Bhagat, S., \& Black, B. (2002). Non-Correlation between Board Independence and Long-Term Firm Performance, The. J. CorP. l., 27, 231.

Breitung, J., \& Lechner, M. (1995). GMM-estimation of nonlinear models on panel data.

Brickley, J. A., \& James, C. M. (1987). The takeover market, corporate board composition, and ownership structure: The case of banking. The Journal of Law \& Economics, 30(1), 161-180. https://doi.org/10.1086/467134

Brickley, J. A., Coles, J. L., \& Terry, R. L. (1994). Outside directors and the adoption of poison pills. Journal of 
Financial Economics, 35(3), 371-390. https://doi.org/10.1016/0304-405X(94)90038-8

Chan, H. W., Lu, Y., \& Zhang, H. F. (2013). The effect of financial constraints, investment policy, product market competition and corporate governance on the value of cash holdings. Accounting \& Finance, 53(2), 339-366. https://doi.org/10.1111/j.1467-629X.2011.00463.x

Chandio, F. H. (2011). Studying acceptance of online banking information system: A structural equation model (Doctoral dissertation, Brunel University Brunel Business School PhD Theses).

Chau, G., \& Leung, P. (2006). The impact of board composition and family ownership on audit committee formation: Evidence from Hong Kong. Journal of International Accounting, Auditing and Taxation, 15(1), 115. https://doi.org/10.1016/j.intaccaudtax.2006.01.001

Cheng, S. (2008). Board size and the variability of corporate performance. Journal of Financial Economics, 87(1), 157-176. https://doi.org/10.1016/j.jfineco.2006.10.006

Cochran, P. L., Wood, R. A., \& Jones, T. B. (1985). The composition of boards of directors and incidence of golden parachutes. Academy of Management Journal, 28(3), 664-671. https://doi.org/10.2307/256121

Coles, J. L., Daniel, N. D., \& Naveen, L. (2008). Boards: Does one size fit all?. Journal of financial economics, 87(2), 329-356. https://doi.org/10.1016/j.jfineco.2006.08.008

Collier, P. (1993). Factors affecting the formation of audit committees in major UK listed companies. Accounting and Business Research, 23(sup1), 421-430. https://doi.org/10.1080/00014788.1993.9729909

Conyon, M. J., \& Peck, S. I. (1998). Board size and corporate performance: evidence from European countries. The European Journal of Finance, 4(3), 291-304. https://doi.org/10.1080/135184798337317

Cornett, M. M., Marcus, A. J., Saunders, A., \& Tehranian, H. (2007). The impact of institutional ownership on corporate operating performance. Journal of Banking \& Finance, 31(6), 1771-1794. https://doi.org/10.1016/j.jbankfin.2006.08.006

Cremers, K. M., \& Romano, R. (2011). Institutional investors and proxy voting on compensation plans: The impact of the 2003 mutual fund voting disclosure rule. American Law and Economics Review. https://doi.org/10.1093/aler/ahq025

Dalton, D. R., Daily, C. M., Johnson, J. L., \& Ellstrand, A. E. (1999). Number of directors and financial performance: A meta-analysis. Academy of Management Journal, 42(6), 674-686. https://doi.org/10.2307/256988

De Villiers, C., Naiker, V., \& Van Staden, C. J. (2011). The effect of board characteristics on firm environmental performance. Journal of Management.

Del Guercio, D., Dann, L. Y., \& Partch, M. M. (2003). Governance and boards of directors in closed-end investment companies. Journal of Financial Economics, 69(1), 111-152. https://doi.org/10.1016/S0304405X(03)00110-7

Ding, B., \& Wermers, R. (2012). Mutual fund performance and governance structure: The role of portfolio managers and boards of directors. https://doi.org/10.2139/ssrn.2207229

Dowers, K. A. (1997). Corporate governance in the mutual fund industry: Board structure and director compensation (Doctoral dissertation, Graduate School of the State University of New York at Buffalo).

Durlauf, S. N., \& Quah, D. T. (1999). The new empirics of economic growth. Handbook of Macroeconomics, 1, 235-308. https://doi.org/10.1016/S1574-0048(99)01007-1

Ebaid, I. (2011). Internal audit function: an exploratory study from Egyptian listed firms. International Journal of law and management, 53(2), 108-128. https://doi.org/10.1108/17542431111119397

Eisenberg, T., Sundgren, S., \& Wells, M. T. (1998). Larger board size and decreasing firm value in small firms. Journal of Financial Economics, 48(1), 35-54. https://doi.org/10.1016/S0304-405X(98)00003-8

Eng, L. L., \& Mak, Y. T. (2003). Corporate governance and voluntary disclosure. Journal of Accounting and Public Policy, 22(4), 325-345. https://doi.org/10.1016/S0278-4254(03)00037-1

Erkens, D. H., Hung, M., \& Matos, P. (2012). Corporate governance in the 2007-2008 financial crisis: Evidence from financial institutions worldwide. Journal of Corporate Finance, 18(2), 389-411. https://doi.org/10.1016/j.jcorpfin.2012.01.005

Ezat, A., \& El-Masry, A. (2008). The impact of corporate governance on the timeliness of corporate internet 
reporting by Egyptian listed companies. Managerial Finance, 34(12), 848-867. https://doi.org/10.1108/03074350810915815

Fama, E. F. (1980). Agency problems and the theory of the firm. The Journal of Political Economy, 288-307. https://doi.org/10.1086/260866

Fama, E. F., \& Jensen, M. C. (1983). Separation of ownership and control. The Journal of Law \& Economics, 26(2), 301-325. https://doi.org/10.1086/467037

Fawzy, (2003). Assessment of corporate governance in Egypt. The Egyptian Centre for Economic Studies Working Paper, 82.

Ferris, S. P., \& Yan, X. S. (2007). Do independent directors and chairmen matter? The role of boards of directors in mutual fund governance. Journal of Corporate Finance, 13(2), 392-420. https://doi.org/10.1016/j.jcorpfin.2006.12.004

Ferris, S. P., Jagannathan, M., \& Pritchard, A. C. (2003). Too busy to mind the business? Monitoring by directors with multiple board appointments. The Journal of Finance, 58(3), 1087-1111. https://doi.org/10.1111/15406261.00559

Forker, J. J. (1992). Corporate governance and disclosure quality. Accounting and Business research, 22(86), 111124. https://doi.org/10.1080/00014788.1992.9729426

Ghazali, N. A. M., \& Weetman, P. (2006). Perpetuating traditional influences: Voluntary disclosure in Malaysia following the economic crisis. Journal of International Accounting, Auditing and Taxation, 15(2), 226-248. https://doi.org/10.1016/j.intaccaudtax.2006.08.001

Gompers, P., Ishii, J., \& Metrick, A. (2003). Corporate governance and equity prices. The Quarterly Journal of Economics, 107-155. https://doi.org/10.1162/00335530360535162

Gottesman, A. A., \& Morey, M. R. (2010). CEO educational background and firm financial performance. Journal of Applied Finance (Formerly Financial Practice and Education), 20(2).

Grace, M., Ireland, A., \& Dunstan, K. (1995). Board composition, non-executive directors' characteristics and corporate financial performance. Asia-Pacific Journal of Accounting, 2(1), 121-137. https://doi.org/10.1080/10293574.1995.10510481

Guest, P. M. (2009). The impact of board size on firm performance: evidence from the UK. The European Journal of Finance, 15(4), 385-404. https://doi.org/10.1080/13518470802466121

Gul, F. A., \& Leung, S. (2004). Board leadership, outside directors"e expertise and voluntary corporate disclosures. Journal of Accounting and Public Policy, 23(5), 351-379. https://doi.org/10.1016/j.jaccpubpol.2004.07.001

Hair, J. F., Black, W. C., Babin, B. J., Anderson, R. E., \& Tatham, R. L. (2006). Multivariate data analysis (Vol. 6). Upper Saddle River, NJ: Pearson Prentice Hall.

Hermalin, B. E., \& Weisbach, M. S. (1991). The effects of board composition and direct incentives on firm performance. Financial Management, 101-112. https://doi.org/10.2307/3665716

Hermalin, B. E., \& Weisbach, M. S. (2001). Boards of directors as an endogenously determined institution: A survey of the economic literature (No. w8161). National Bureau of Economic Research. https://doi.org/10.3386/w8161

Huber, M., \& Mellace, G. (2013). Sharp IV bounds on policy relevant parameters under endogeneity and noncompliance.

Ibrahim, N. A., Zin, N. N. M., Kassim, A. A. M., \& Tamsir, F. (2019). How Does Directors' Remuneration and Board Structure Impact on Firm Performance in Malaysia Telecommunication Industry?. European Journal of Business and Management Research, 4(4). https://doi.org/10.24018/ejbmr.2019.4.4.96

Jensen, M. C. (1993). The modern industrial revolution, exit, and the failure of internal control systems. The Journal of Finance, 48(3), 831-880. https://doi.org/10.1111/j.1540-6261.1993.tb04022.x

Jones, M. (2007). Examination of fund age and size and its impact on hedge fund performance. Derivatives Use, Trading Regulation, 12(4), 342-350. https://doi.org/10.1057/palgrave.dutr.1850052

Khorana, A., Tufano, P., \& Wedge, L. (2007). Board structure, mergers, and shareholder wealth: A study of the mutual fund industry. Journal of Financial Economics, 85(2), 571-598. https://doi.org/10.1016/j.jfineco.2006.05.002 
Kirkpatrick, G. (2009). The corporate governance lessons from the financial crisis. OECD Journal: Financial Market Trends, 2009(1), 61-87. https://doi.org/10.1787/fmt-v2009-art3-en

Klein, A. (1998). Firm performance and board committee structure 1. The Journal of Law and Economics, 41(1), 275-304. https://doi.org/10.1086/467391

Klein, A., \& Zur, E. (2011). The impact of hedge fund activism on the target firm's existing bondholders. Review of Financial Studies, p.hhr016. https://doi.org/10.1093/rfs/hhr016

Kryzanowski, L., \& Mohebshahedin, M. (2016). Board governance, monetary interest, and closed-end fund performance. Journal of Corporate Finance, 38, 196-217. https://doi.org/10.1016/j.jcorpfin.2016.01.010

Lam, T. Y., \& Lee, S. K. (2012). Family ownership, board committees and firm performance: evidence from Hong Kong. Corporate Governance: The International Journal of Business in Society, 12(3), 353-366. https://doi.org/10.1108/14720701211234609

Lassoued, N., \& Elmir, A. (2012). Portfolio selection: does corporate governance matter? Corporate Governance: The International Journal of Business in Society, 12(5), 701-713. https://doi.org/10.1108/14720701211275613

Lin, Y. F. (2005). Corporate governance, leadership structure and CEO compensation: Evidence from Taiwan. Corporate Governance: An International Review, 13(6), 824-835. https://doi.org/10.1111/j.14678683.2005.00473.x

Lipton, M., \& Lorsch, J. W. (1992). A modest proposal for improved corporate governance. The Business Lawyer, 59-77.

Mak, Y. T., \& Li, Y. (2001). Determinants of corporate ownership and board structure: evidence from Singapore. Journal of Corporate Finance, 7(3), 235-256. https://doi.org/10.1016/S0929-1199(01)00021-9

Mehran, H. (1995). Executive compensation structure, ownership, and firm performance. Journal of Financial Economics, 38(2), 163-184. https://doi.org/10.1016/0304-405X(94)00809-F

Morck, R., Shleifer, A., \& Vishny, R. W. (1988). Management ownership and market valuation: An empirical analysis. Journal of Financial Economics, 20, 293-315. https://doi.org/10.1016/0304-405X(88)90048-7

Patel, M. A. (2019). Impact of Board Structure and Firm Performance on Chief Executive's Compensation. AsiaPacific Management Accounting Journal, 14(2), 185-199.

Pincus, K., Rusbarsky, M., \& Wong, J. (1989). Voluntary formation of corporate audit committees among NASDAQ firms. Journal of Accounting and Public Policy, 8(4), 239-265. https://doi.org/10.1016/02784254(89)90014-8

Rediker, K. J., \& Seth, A. (1995). Boards of directors and substitution effects of alternative governance mechanisms. Strategic Management Journal, 16(2), 85-99. https://doi.org/10.1002/smj.4250160202

Roberts, M. R., \& Whited, T. M. (2012). Endogeneity in empirical corporate finance. https://doi.org/10.2139/ssrn.1748604

Rosenstein, S., \& Wyatt, J. G. (1990). Outside directors, board independence, and shareholder wealth. Journal of Financial Economics, 26(2), 175-191. https://doi.org/10.1016/0304-405X(90)90002-H

Rundle-Thiele, S., Ball, K., \& Gillespie, M. (2008). Raising the bar: from corporate social responsibility to corporate social performance. Journal of Consumer Marketing, 25(4), 245-253. https://doi.org/10.1108/07363760810882434

Samaha, K., \& Dahawy, K. (2010). Factors influencing voluntary corporate disclosure by the actively traded Egyptian firms. Research in Accounting in Emerging Economies, 10, 87-119. https://doi.org/10.1108/S14793563(2010)0000010009

Samaha, K., \& Dahawy, K. (2011). An empirical analysis of corporate governance structures and voluntary corporate disclosure in volatile capital markets: The Egyptian experience. International Journal of Accounting, Auditing and Performance Evaluation, 7(1-2), 61-93. https://doi.org/10.1504/IJAAPE.2011.037726

Samaha, K., Dahawy, K., Hussainey, K., \& Stapleton, P. (2012). The extent of corporate governance disclosure and its determinants in a developing market: The case of Egypt. Advances in Accounting, 28(1), 168-178. https://doi.org/10.1016/j.adiac.2011.12.001

Sharma, D. S., Boo, E. F., \& Sharma, V. D. (2008). The impact of non-mandatory corporate governance on 
auditors" client acceptance, risk and planning judgments. Accounting and Business Research, 38(2), 105-120. https://doi.org/10.1080/00014788.2008.9663324

Short, H., \& Keasey, K. (1999). Managerial ownership and the performance of firms: Evidence from the UK. Journal of Corporate Finance, 5(1), 79-101.

Singh, M., Mathur, I., \& Gleason, K. C. (2004). Governance and performance implications of diversification strategies: Evidence from large US firms. Financial Review, 39(4), 489-526. https://doi.org/10.1111/j.07328516.2004.00086.x

Tam, O. K., \& Tan, M. G. S. (2007). Ownership, governance and firm performance in Malaysia. Corporate Governance: An International Review, 15(2), 208-222. https://doi.org/10.1111/j.1467-8683.2007.00555.x

Tufano, P., \& Sevick, M. (1997). Board structure and fee-setting in the US mutual fund industry. Journal of Financial Economics, 46(3), 321-355. https://doi.org/10.1016/S0304-405X(97)00033-0

Walters, B. A., Kroll, M. J., \& Wright, P. (2007). CEO tenure, boards of directors, and acquisition performance. Journal of Business Research, 60(4), 331-338. https://doi.org/10.1016/j.jbusres.2006.12.001

Wang, M., \& Hussainey, K. (2013). Voluntary forward-looking statements driven by corporate governance and their value relevance. Journal of Accounting and Public Policy, 32(3), 26-49. https://doi.org/10.1016/j.jaccpubpol.2013.02.009

Weir, C., \& Laing, D. (2003). Ownership structure, board composition and the market for corporate control in the UK: an empirical analysis. Applied Economics, 35(16), 1747-1759. https://doi.org/10.1080/0003684032000155454

Westland, J. C. (2010). Lower bounds on sample size in structural equation modeling. Electronic Commerce Research and Applications, 9(6), 476-487. https://doi.org/10.1016/j.elerap.2010.07.003

Wintoki, M. B., Linck, J. S., \& Netter, J. M. (2012). Endogeneity and the dynamics of internal corporate governance. Journal of Financial Economics, 105(3), 581-606. https://doi.org/10.1016/j.jfineco.2012.03.005

Yermack, D. (1996). Higher market valuation of companies with a small board of directors. Journal of Financial Economics, 40(2), 185-211. https://doi.org/10.1016/0304-405X(95)00844-5

Zhang, P. (2010). Board information and strategic tasks performance. Corporate Governance: An International Review, 18(5), 473-487. https://doi.org/10.1111/j.1467-8683.2010.00816.x

\section{Appendix}

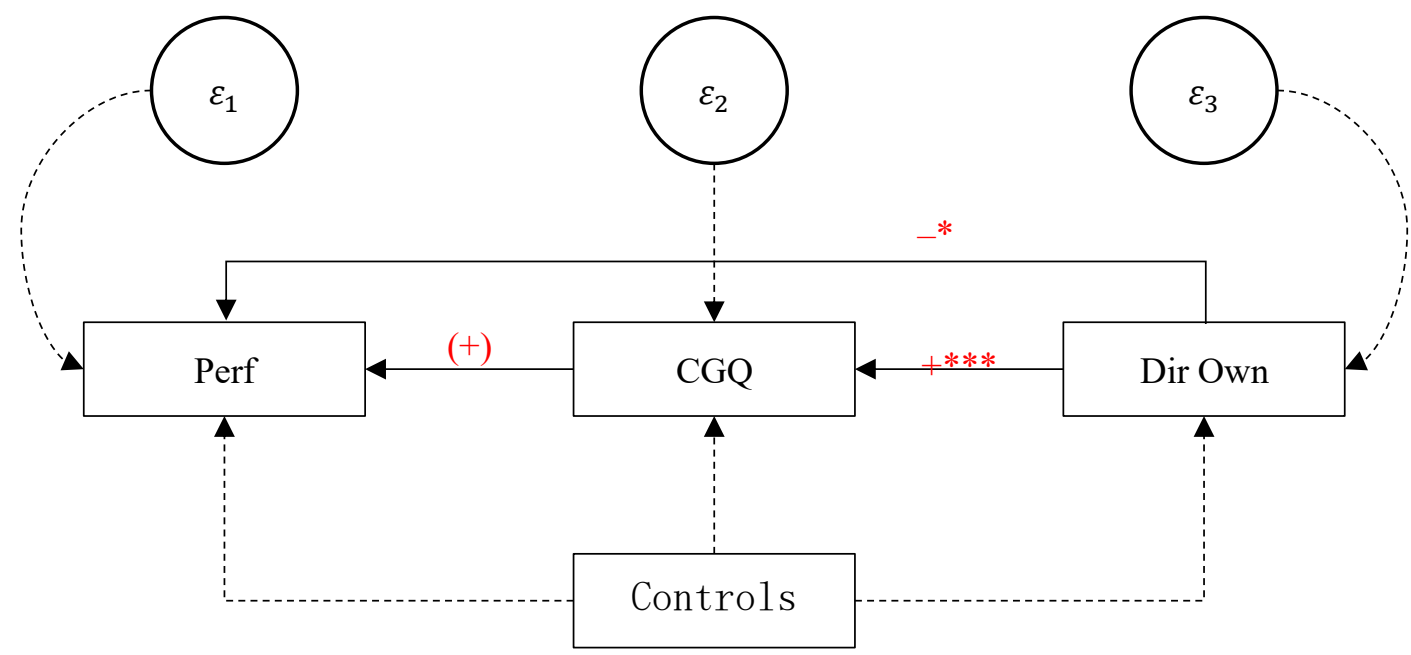

Figure 1. Path diagram of the structural equation model

Note. $* 10 \%$ level, $* * 5 \%$ level, $* * * 1 \%$ level, $(+)$ positive but not significant. 
Table 1. Empirical analysis of the effect of board structure on performance

\begin{tabular}{|c|c|c|c|c|c|}
\hline Paper & Sample & Period & Performance Measure & Methodology & Relationship \\
\hline \multicolumn{6}{|c|}{ Papers examining relationship between board independence and firm performance } \\
\hline Bhagat and Black (2002) & 934 & $1988-1991$ & Q, ROA, ROS, Market & OLS, 2SLS & Negative \\
\hline $\begin{array}{l}\text { Coles, Daniel, and } \\
\text { Naveen (2008) }\end{array}$ & 8,165 & 1992-2001 & Q & OLS, 3SLS & $\begin{array}{l}\text { Negative for Development } \\
\text { (R\&D) firms }\end{array}$ \\
\hline Ding and Wermers (2012) & 2,689 & 1985-2002 & $\begin{array}{l}\text { (alpha) from four-factor } \\
\text { model, (CS) measure }\end{array}$ & OLS & Positive \\
\hline Ferris and Yan (2007) & 531 & $2002-2003$ & fund's total return & OLS, 2SLS & None \\
\hline Rashid et al. (2010) & 90 & 2005-2009 & Q, ROA & OLS & None \\
\hline \multicolumn{6}{|c|}{ Papers examining relationship between board size and firm performance } \\
\hline $\begin{array}{l}\text { Coles, Daniel, and } \\
\text { Naveen (2008) }\end{array}$ & 8,165 & $1992-2001$ & Q & OLS, 3SLS & $\begin{array}{l}\text { Positive for large diversified } \\
\text { firms }\end{array}$ \\
\hline Cheng (2008) & 1,252 & 1996-2004 & $\begin{array}{l}\text { monthly stock returns, } \\
\text { ROA, and } \mathrm{Q} \text {, }\end{array}$ & OLS & Negative \\
\hline Guest (2009) & 2746 & $1981-2002$ & Q and ROA & OLS, GMM & Negative for large firms \\
\hline Ding and Wermers (2012) & 2,689 & $1985-2002$ & $\begin{array}{l}\text { (alpha) from four-factor } \\
\text { model, (CS) measure }\end{array}$ & OLS & Positive \\
\hline Rashid et al. (2010) & 90 & 2005-2009 & Q, ROA & OLS & Negative \\
\hline
\end{tabular}

Source: Wintoki, et al. (2012).

Table 2. Summary of endogenous, exogenous and control variables

\begin{tabular}{|c|c|c|}
\hline Endogenous Variables & Measures & Source \\
\hline $\begin{array}{l}\text { Mutual funds financial } \\
\text { performance }\left(\operatorname{Per} f_{i t}\right)\end{array}$ & $\begin{aligned} R_{i t} & =\frac{1}{n} \sum_{i=1}^{n} R_{i} \\
T I_{i t} & =\frac{\left(R_{i t}-R_{f t}\right)}{\beta_{i}} \\
S I_{i t} & =\frac{\left(R_{i t}-R_{f t}\right)}{\sigma_{i}}\end{aligned}$ & $\begin{array}{l}\text { Calculated from mutual fund's } \\
\text { prospectuses, mutual fund's } \\
\text { financial statements, and } \\
\text { economic review of Central Bank } \\
\text { of Egypt. }\end{array}$ \\
\hline $\begin{array}{l}\text { Corporate governance } \\
\text { index }(C G Q)\end{array}$ & 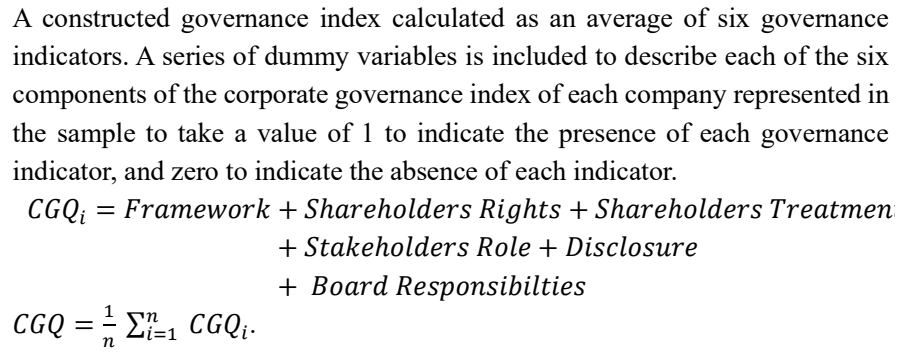 & $\begin{array}{l}\text { Calculated from the annual } \\
\text { reports of the fund management } \\
\text { companies and the companies' } \\
\text { websites. }\end{array}$ \\
\hline $\begin{array}{l}\text { Equity ownership by } \\
\text { directors }\left(\operatorname{Dir}_{O w n}\right)\end{array}$ & The number of directors holding zero shares divided by board size. & $\begin{array}{l}\text { Board of director's annual reports } \\
\text { of Egyptian funds. }\end{array}$ \\
\hline Exogenous Variables & Measures & Source \\
\hline Board size $\left(B_{\text {Size }}\right)$ & The size of the board. & $\begin{array}{l}\text { Board of director's annual reports } \\
\text { of Egyptian mutual. }\end{array}$ \\
\hline $\begin{array}{l}\text { Proportion of independent } \\
\text { directors }\left(\text { Ind }_{\text {Dir }}\right)\end{array}$ & $\begin{array}{l}\text { the number of independent directors on the board divided by board size. } \\
\text { The directors' background. }\end{array}$ & $\begin{array}{l}\text { Board of director's annual reports } \\
\text { of Egyptian funds. }\end{array}$ \\
\hline $\begin{array}{l}\text { Director's background } \\
\left(\text { Fin }_{\text {Dir }}, \text { Prof }_{\text {Dir }}\right)\end{array}$ & $\begin{array}{l}\text { The number of directors with a background in finance or investment divided } \\
\text { by board size. } \\
\text { The number of directors who are retired or serve on several different boards as } \\
\text { professional directors divided by board size. }\end{array}$ & $\begin{array}{l}\text { Board of director's annual reports } \\
\text { of Egyptian funds. }\end{array}$ \\
\hline $\begin{array}{l}\text { Board committee } \\
\text { structure } \\
\left(\text { Inv }_{\text {Comm }}, A u d_{\text {Comm }}\right)\end{array}$ & $\begin{array}{l}\text { The number of directors on the investment committee divided by board size. } \\
\text { The number of directors on the audit committee divided by board size. }\end{array}$ & $\begin{array}{l}\text { Board of director's annual reports } \\
\text { of Egyptian mutual funds. }\end{array}$ \\
\hline $\begin{array}{l}\text { Number of funds } \\
\text { overseen by the fund } \\
\text { management } \\
\text { company }\left(\text { Dir }_{F n}\right)\end{array}$ & The number of funds overseen by the fund management company. & $\begin{array}{l}\text { Board of director's annual reports } \\
\text { of Egyptian mutual funds. }\end{array}$ \\
\hline $\begin{array}{l}\text { Director's } \\
\text { tenure }\left(\operatorname{Dir}_{T n}\right)\end{array}$ & $\begin{array}{l}\text { The average number of years the firm's directors have served on the board } \\
\text { either the fund management company board or any other boards. }\end{array}$ & $\begin{array}{l}\text { Board of director's annual reports } \\
\text { of Egyptian mutual funds. }\end{array}$ \\
\hline
\end{tabular}




\begin{tabular}{lll}
\hline Control Variables & Measures & Source \\
\hline Time & The years dummies between 2004-2013. & Sample Period. \\
Investment objective & This study uses dummy variables for the investment objectives represented in & \\
dummy variables & the sample, to take a value of 1 if the fund belongs to the same category under & Mutual fund prospectuses. \\
(Fund $\left.{ }_{o b j}\right)$ & study and zero otherwise. & \\
$\begin{array}{ll}\text { Standard Deviation of the } \\
\text { Stock Return }\left(\sigma_{i}\right)\end{array}$ & The standard deviation of mutual fund returns. & Calculated. \\
\hline
\end{tabular}

Table 3. Descriptive statistics of board structure and fund performance

\begin{tabular}{|c|c|c|c|c|c|c|c|c|c|c|c|c|}
\hline \multicolumn{13}{|c|}{ Panel A: Fund and Governance Descriptive Statistics } \\
\hline \multirow[b]{3}{*}{ Variable } & \multirow{2}{*}{\multicolumn{4}{|c|}{$\begin{array}{c}\text { Model 1 } \\
\text { Number of obs }=932\end{array}$}} & \multirow{2}{*}{\multicolumn{4}{|c|}{$\begin{array}{c}\text { Model 2 } \\
\text { Number of obs }=932\end{array}$}} & \multirow{2}{*}{\multicolumn{4}{|c|}{$\begin{array}{c}\text { Model 3 } \\
\text { Number of obs }=932\end{array}$}} \\
\hline & & & & & & & & & & & & \\
\hline & Mean & Std. Dev. & Min & Max & Mean & Std. Dev. & Min & Max & Mean & Std. Dev. & Min & Max \\
\hline Perf1 & 0.0016 & 0.0049 & -0.0153 & 0.016169 & & & & & & & & \\
\hline Perf2 & & & & & -0.4960 & 1.1348 & -7.7820 & 1.0071 & & & & \\
\hline Perf3 & & & & & & & & & -0.1596 & 3.9083 & -77.3124 & 33.8197 \\
\hline CGQ & 0.5848 & 0.1650 & 0.1667 & 0.8333 & 0.5848 & 0.1650 & 0.1667 & 0.8333 & 0.5848 & 0.1650 & 0.1667 & 0.8333 \\
\hline DirOwn & 0.8420 & 0.2348 & 0.0000 & 1.0000 & 0.8420 & 0.2348 & 0.0000 & 1.0000 & 0.8420 & 0.2348 & 0.0000 & 1.0000 \\
\hline FundObj5 & 0.2361 & 0.4249 & 0.0000 & 1.0000 & 0.2361 & 0.4249 & 0.0000 & 1.0000 & 0.2361 & 0.4249 & 0.0000 & 1.0000 \\
\hline FundObj4 & 0.1073 & 0.3097 & 0.0000 & 1.0000 & 0.1073 & 0.3097 & 0.0000 & 1.0000 & 0.1073 & 0.3097 & 0.0000 & 1.0000 \\
\hline FundObj3 & 0.1309 & 0.3375 & 0.0000 & 1.0000 & 0.1309 & 0.3375 & 0.0000 & 1.0000 & 0.1309 & 0.3375 & 0.0000 & 1.0000 \\
\hline FundObj2 & 0.3605 & 0.4804 & 0.0000 & 1.0000 & 0.3605 & 0.4804 & 0.0000 & 1.0000 & 0.3605 & 0.4804 & 0.0000 & 1.0000 \\
\hline FundObj1 & 0.0279 & 0.1648 & 0.0000 & 1.0000 & 0.0279 & 0.1648 & 0.0000 & 1.0000 & 0.0279 & 0.1648 & 0.0000 & 1.0000 \\
\hline Dump & 0.5000 & 0.5003 & 0.0000 & 1.0000 & 0.5000 & 0.5003 & 0.0000 & 1.0000 & 0.5000 & 0.5003 & 0.0000 & 1.0000 \\
\hline Time & 2009.79 & 2.6789 & 2004.00 & 2013.00 & 2009.79 & 2.6789 & 2004.00 & 2013.00 & 2009.79 & 2.6789 & 2004.00 & 2013.00 \\
\hline DirTn & 19.0011 & 6.1760 & 6.0000 & 29.0000 & 19.0011 & 6.1760 & 6.0000 & 29.0000 & 19.0011 & 6.1760 & 6.0000 & 29.0000 \\
\hline ProfDir & 0.4192 & 0.3156 & 0.0909 & 1.0000 & 0.4192 & 0.3156 & 0.0909 & 1.0000 & 0.4192 & 0.3156 & 0.0909 & 1.0000 \\
\hline AudComm & 0.2741 & 0.1158 & 0.0909 & 0.5000 & 0.2741 & 0.1158 & 0.0909 & 0.5000 & 0.2741 & 0.1158 & 0.0909 & 0.5000 \\
\hline BSize & 8.8680 & 3.1024 & 3.0000 & 17.0000 & 8.8680 & 3.1024 & 3.0000 & 17.0000 & 8.8680 & 3.1024 & 3.0000 & 17.0000 \\
\hline InvComm & 0.1886 & 0.1269 & 0.0588 & 0.5455 & 0.1886 & 0.1269 & 0.0588 & 0.5455 & 0.1886 & 0.1269 & 0.0588 & 0.5455 \\
\hline DirFn & 9.7135 & 5.0942 & 1.0000 & 15.0000 & 9.7135 & 5.0942 & 1.0000 & 15.0000 & 9.7135 & 5.0942 & 1.0000 & 15.0000 \\
\hline FinDir & 0.3450 & 0.2171 & 0.0909 & 0.8000 & 0.3450 & 0.2171 & 0.0909 & 0.8000 & 0.3450 & 0.2171 & 0.0909 & 0.8000 \\
\hline IndDir & 0.8096 & 0.2424 & 0.0000 & 1.0000 & 0.8096 & 0.2424 & 0.0000 & 1.0000 & 0.8096 & 0.2424 & 0.0000 & 1.0000 \\
\hline StdDev i & 0.0184 & 0.0144 & 0.0000 & 0.0602 & & & & & & & & \\
\hline
\end{tabular}

Table 4. Estimated path coefficients of the SEMs

\begin{tabular}{llll}
\hline Equation & Model 1 & Model 2 & Model 3 \\
\hline Perf & & & 0.6414 \\
\hline CGQ & 0.0006 & 0.0145 & 0.8654 \\
Dir Own & 0.0020 & $-0.8908^{* *}$ & $-1.0128^{*}$ \\
Fund Obj5 & $-0.0023^{* * *}$ & $-1.4480^{* * *}$ & -0.1628 \\
Fund Obj4 & $0.0021^{* *}$ & $0.3722^{* * *}$ & -0.3382 \\
Fund Obj3 & 0.0012 & $0.3897^{* * *}$ & -0.1568 \\
Fund Obj2 & $0.0030^{* * *}$ & $0.3299^{* * *}$ & 0.1519 \\
Fund Obj1 & -0.0014 & $-0.5204^{* *}$ & -0.2888 \\
Dump & 0.0003 & $0.1009^{*}$ & -0.0245 \\
Time & $-0.0005^{* * *}$ & $-0.0939^{* * *}$ & 0.0260 \\
Dir Tn & -0.0000 & 0.0066 & 0.2290 \\
Prof Dir & 0.0011 & $1.1817^{*}$ & 0.1169 \\
Aud Comm & 0.0020 & -0.6722 & -0.0768 \\
B Size & -0.0001 & $0.0591^{* *}$ & 0.7073 \\
Inv Comm & -0.0000 & 0.1524 & -0.0370 \\
Dir Fn & 0.0001 & $-0.0202^{*}$ & -0.4182 \\
Fin Dir & -0.0028 & $-2.5017^{* * *}$ & 0.1743 \\
Ind Dir & -0.0018 & $0.5637^{*}$ & \\
StdDev i & $-0.2081^{* * *}$ & & 48.8607 \\
Constant & $0.9205^{* * *}$ & $188.66^{* * *}$ & \\
\hline
\end{tabular}




\begin{tabular}{|c|c|c|c|}
\hline CGQ & & & \\
\hline Dir Own & $0.0998^{* * *}$ & $0.0998 * * *$ & $0.0998 * * *$ \\
\hline Fund Obj5 & $0.0443 * * *$ & $0.0443^{* * *}$ & $0.0443 * * *$ \\
\hline Fund Obj4 & $0.0465^{* * *}$ & $0.0465^{* * *}$ & $0.0465^{* * *}$ \\
\hline Fund Obj3 & $0.0307 * *$ & $0.0307 * *$ & $0.0307 * *$ \\
\hline Fund Obj2 & $0.0216^{* *}$ & $0.0216^{* *}$ & $0.0216^{* *}$ \\
\hline Fund Obj1 & $0.0521^{* * *}$ & $0.0521^{* * *}$ & $0.0521^{* * *}$ \\
\hline Dir Tn & $-0.0095^{* * *}$ & $-0.0095 * * *$ & $-0.0095 * * *$ \\
\hline Prof Dir & $0.4255 * * *$ & $0.4255^{* * *}$ & $0.4255^{* * *}$ \\
\hline Aud Comm & $0.4015^{* * *}$ & $0.4015^{* * *}$ & $0.4015^{* * *}$ \\
\hline B Size & $0.0124 * * *$ & $0.0124 * * *$ & $0.0124 * * *$ \\
\hline Inv Comm & -0.0333 & -0.0333 & -0.0333 \\
\hline Dir Fn & $0.0146^{* * *}$ & $0.0146^{* * *}$ & $0.0146^{* * *}$ \\
\hline Fin Dir & $-0.2357 * * *$ & $-0.2357 * * *$ & $-0.2357 * * *$ \\
\hline Ind Dir & $-0.1463^{* * *}$ & $-0.1463 * * *$ & $-0.1463 * * *$ \\
\hline Constant & $0.3177 * * *$ & $0.3177 * * *$ & $0.3177 * * *$ \\
\hline \multicolumn{4}{|l|}{ Dir Own } \\
\hline Fund Obj5 & 0.0650 *** & $0.0650^{* * *}$ & $0.0650^{* * *}$ \\
\hline Fund Obj4 & $0.0689 * * *$ & $0.0689 * * *$ & $0.0689 * * *$ \\
\hline Fund Obj3 & $0.1450 * * *$ & $0.1450^{* * *}$ & $0.1450^{* * *}$ \\
\hline Fund Obj2 & $0.0794 * * *$ & $0.0794 * * *$ & $0.0794 * * *$ \\
\hline Fund Obj1 & $0.0883^{* * *}$ & $0.0883^{* * *}$ & $0.0883^{* * *}$ \\
\hline Dir Tn & -0.0012 & -0.0012 & -0.0012 \\
\hline Prof Dir & $-0.2624 * * *$ & $-0.2624 * * *$ & $-0.2624 * * *$ \\
\hline Aud Comm & 0.0515 & 0.0515 & 0.0515 \\
\hline B Size & $0.0440 * * *$ & $0.0440^{* * *}$ & $0.0440 * * *$ \\
\hline Inv Comm & 0.0407 & 0.0407 & 0.0407 \\
\hline Dir Fn & $-0.0095^{* * *}$ & $-0.0095 * * *$ & $-0.0095 * * *$ \\
\hline Fin Dir & $0.2298 * *$ & $0.2298 * *$ & $0.2298 * *$ \\
\hline Ind Dir & $0.7272 * * *$ & $0.7272 * * *$ & $0.7272 * * *$ \\
\hline Constant & $-0.0852 * *$ & $-0.0852 * *$ & $-0.0852 * *$ \\
\hline \multicolumn{4}{|l|}{$\operatorname{var}(\mathrm{e}$. Perf1) } \\
\hline $\begin{array}{l}\text { Constant } \\
\text { var(e.Perf2) }\end{array}$ & $0.0000^{* * *}$ & & \\
\hline $\begin{array}{l}\text { Constant } \\
\text { var(e.Perf3) }\end{array}$ & & $0.6082 * * *$ & \\
\hline $\begin{array}{l}\text { Constant } \\
\operatorname{var}(\mathrm{e} . \mathrm{CGQ})\end{array}$ & & & $15.0616^{* * *}$ \\
\hline $\begin{array}{l}\text { Constant } \\
\text { var(e.DirOwn) }\end{array}$ & $0.0047 * * *$ & $0.0047^{* * *}$ & $0.0047 * * *$ \\
\hline Constant & $0.0079 * * *$ & $0.0079 * * *$ & $0.0079 * * *$ \\
\hline Observations & 932 & 932 & 932 \\
\hline
\end{tabular}

Note. This table provides results from SEM of the effect of board structure on mutual fund performance for the sample of 82 funds from 2004 2013. In Model 1, mutual fund performance is measured by the absolute return, in Model 2 mutual fund performance is measured by Sharp ratio, and in Model 3, mutual fund performance is measured by Treynor ratio. * Statistical significance at $10 \%$ level, ** Statistical significance at $5 \%$ level, *** Statistical significance at $1 \%$ level. 
Table 5. Direct, indirect and total effects of the estimated structural equation model

Panel A: The Effects of Board Structure on Mutual Fund Performance (Perf)

\begin{tabular}{|c|c|c|c|c|c|c|c|c|c|c|c|c|c|c|c|c|c|c|}
\hline & \multicolumn{6}{|c|}{ Direct Effect } & \multicolumn{6}{|c|}{ Indirect Effect } & \multicolumn{6}{|c|}{ Total Effect } \\
\hline & \multicolumn{2}{|c|}{ Model 1} & \multicolumn{2}{|c|}{ Model 2} & \multicolumn{2}{|c|}{ Model 3} & \multicolumn{2}{|c|}{ Model 1} & \multicolumn{2}{|c|}{ Model 2} & \multicolumn{2}{|c|}{ Model 3} & \multicolumn{2}{|c|}{ Model 1} & \multicolumn{2}{|c|}{ Model 2} & \multicolumn{2}{|c|}{ Model 3} \\
\hline & Effect & P-val & Effect & P-val & Effect & P-val & Effect & P-val & Effect & P-val & Effect & P-val & Effect & P-val & Effect & P-val & Effect & P-val \\
\hline CGQ & 0.001 & 0.790 & 0.015 & 0.969 & 0.641 & 0.730 & & & & & & & 0.001 & 0.790 & 0.015 & 0.969 & 0.641 & 0.730 \\
\hline DirOwn & 0.002 & 0.220 & -0.891 & 0.002 & 0.865 & 0.549 & 0.000 & 0.000 & 0.001 & 0.000 & 0.064 & 0.000 & 0.002 & 0.208 & -0.889 & 0.002 & 0.929 & 0.520 \\
\hline FundObj5 & -0.002 & 0.000 & -1.448 & 0.000 & -1.013 & 0.046 & 0.000 & 0.266 & -0.057 & 0.033 & 0.089 & 0.477 & -0.002 & 0.001 & -1.505 & 0.000 & -0.924 & 0.061 \\
\hline FundObj4 & 0.002 & 0.002 & 0.372 & 0.001 & -0.163 & 0.771 & 0.000 & 0.265 & -0.061 & 0.034 & 0.094 & 0.477 & 0.002 & 0.001 & 0.312 & 0.005 & -0.069 & 0.899 \\
\hline FundObj3 & 0.001 & 0.057 & 0.390 & 0.000 & -0.338 & 0.541 & 0.000 & 0.198 & -0.129 & 0.004 & 0.155 & 475 & 002 & 0.009 & 0.261 & 0.011 & -0.184 & 0.719 \\
\hline FundObj2 & 0.003 & 0.000 & 0.330 & 0.000 & -0.157 & 0.735 & 0.000 & 0.204 & -0.070 & 0.007 & 0.088 & 0.470 & 0.003 & 0.000 & 0.260 & 0.004 & -0.069 & 0.877 \\
\hline FundObj1 & -0.001 & 0.187 & -0.520 & 0.003 & 0.152 & 0.863 & 0.000 & 0.254 & -0.078 & 0.033 & 0.116 & 0.473 & -0.001 & 0.259 & -0.598 & 0.001 & 0.267 & 0.758 \\
\hline Dump & 0.000 & 0.240 & 0.101 & 0.048 & -0.289 & 0.256 & & & & & & & 0.000 & 0.240 & 0.101 & 0.048 & -0.289 & 0.256 \\
\hline Time & -0.001 & 0.000 & -0.094 & 0.000 & -0.025 & 0.629 & & & & & & & -0.001 & 0.000 & -0.094 & 0.000 & -0.025 & 0.629 \\
\hline DirTn & 0.000 & 0.244 & 0.007 & 0.319 & 0.026 & 0.429 & 0.000 & 0.698 & 0.001 & 0.795 & -0.007 & 0.684 & 0.000 & 0.104 & 0.008 & 0.180 & 0.019 & 0.498 \\
\hline ProfDir & 0.001 & 0.692 & 1.182 & 0.017 & 0.229 & 0.926 & 0.000 & 0.761 & 0.240 & 0.187 & 0.029 & 0.974 & 0.001 & 0.758 & 1.421 & 0.002 & 0.258 & 0.911 \\
\hline AudComm & 0.002 & 0.401 & -0.672 & 0.110 & 0.117 & 0.955 & 0.000 & 0.698 & -0.040 & 0.797 & 0.305 & 0.684 & 0.002 & 0.295 & -0.712 & 0.071 & 0.422 & 0.829 \\
\hline BSize & 0.000 & 0.612 & 0.059 & 0.001 & -0.077 & 0.395 & 0.000 & 0.200 & -0.039 & 0.004 & 0.049 & 0.467 & 0.000 & 0.498 & 0.020 & 0.095 & -0.028 & 0.640 \\
\hline InvComm & 0.000 & 0.976 & 0.152 & 0.598 & 0.707 & 0.623 & 0.000 & 0.581 & -0.037 & 0.278 & 0.017 & 0.858 & 0.000 & 0.992 & 0.116 & 0.690 & 0.724 & 0.615 \\
\hline DirFn & 0.000 & 0.365 & -0.020 & 0.045 & -0.037 & 0.460 & 0.000 & 0.739 & 0.009 & 0.158 & 0.001 & 0.986 & 0.000 & 0.378 & -0.012 & 0.153 & -0.036 & 0.359 \\
\hline FinDir & -0.003 & 0.491 & -2.502 & 0.000 & -0.418 & 0.906 & 0.000 & 0.594 & -0.208 & 0.112 & 0.062 & 0.910 & -0.003 & 0.542 & -2.709 & 0.000 & -0.356 & 0.919 \\
\hline IndDir & -0.002 & 0.239 & 0.564 & 0.037 & 0.174 & 0.897 & 0.001 & 0.245 & -0.649 & 0.003 & 0.582 & 0.589 & 0.000 & 0.681 & -0.085 & 0.606 & 0.756 & 0.355 \\
\hline
\end{tabular}

Panel B: The effects of board structure on Corporate Governance (CGQ)

\begin{tabular}{|c|c|c|c|c|c|c|c|c|c|c|c|c|c|c|c|c|c|c|}
\hline & \multicolumn{6}{|c|}{ Direct Effect } & \multicolumn{6}{|c|}{ Indirect Effect } & \multicolumn{6}{|c|}{ Total Effect } \\
\hline & \multicolumn{2}{|c|}{ Model 1} & \multicolumn{2}{|c|}{ Model 2} & \multicolumn{2}{|c|}{ Model 3} & \multicolumn{2}{|c|}{ Model 1} & \multicolumn{2}{|c|}{ Model 2} & \multicolumn{2}{|c|}{ Model 3} & \multicolumn{2}{|c|}{ Model 1} & \multicolumn{2}{|c|}{ Model 2} & \multicolumn{2}{|c|}{ Model 3} \\
\hline & Effect & P-val & Effect & P-val & Effect & P-val & Effect & P-val & Effect & P-val & Effect & P-val & Effect & P-val & Effect & P-val & Effect & P-val \\
\hline DirOwn & 0.100 & 0.000 & 0.100 & 0.000 & 0.100 & 0.000 & & & & & & & 0.100 & 0.000 & 0.100 & 0.000 & 0.100 & 0.000 \\
\hline FundObj5 & 0.044 & 0.000 & 0.044 & 0.000 & 0.044 & 0.000 & 0.007 & 0.001 & 0.007 & 0.001 & 0.007 & 0.001 & 0.051 & 0.000 & 0.051 & 0.000 & 0.051 & 0.000 \\
\hline FundObj4 & 0.047 & 0.000 & 0.047 & 0.000 & 0.047 & 0.000 & 0.007 & 0.001 & 0.007 & 0.001 & 0.007 & 0.001 & 0.053 & 0.000 & 0.053 & 0.000 & 0.053 & 0.000 \\
\hline FundObj3 & 0.031 & 0.002 & 0.031 & 0.002 & 0.031 & 0.002 & 0.015 & 0.000 & 0.015 & 0.000 & 0.015 & 0.000 & 0.045 & 0.000 & 0.045 & 0.000 & 0.045 & 0.000 \\
\hline FundObj2 & 0.022 & 0.008 & 0.022 & 0.008 & 0.022 & 0.008 & 0.008 & 0.000 & 0.008 & 0.000 & 0.008 & 0.000 & 0.030 & 0.000 & 0.030 & 0.000 & 0.030 & 0.000 \\
\hline FundObj1 & 0.052 & 0.001 & 0.052 & 0.001 & 0.052 & 0.001 & 0.009 & 0.003 & 0.009 & 0.003 & 0.009 & 0.003 & 0.061 & 0.000 & 0.061 & 0.000 & 0.061 & 0.000 \\
\hline DirTn & -0.010 & 0.000 & -0.010 & 0.000 & -0.010 & 0.000 & 0.000 & 0.086 & 0.000 & 0.086 & 0.000 & 0.086 & -0.010 & 0.000 & -0.010 & 0.000 & -0.010 & 0.000 \\
\hline ProfDir & 0.426 & 0.000 & 0.426 & 0.000 & 0.426 & 0.000 & -0.026 & 0.002 & -0.026 & 0.002 & -0.026 & 0.002 & 0.399 & 0.000 & 0.399 & 0.000 & 0.399 & 0.000 \\
\hline AudComm & 0.402 & 0.000 & 0.402 & 0.000 & 0.402 & 0.000 & 0.005 & 0.268 & 0.005 & 0.268 & 0.005 & 0.268 & 0.407 & 0.000 & 0.407 & 0.000 & 0.407 & 0.000 \\
\hline BSize & 0.012 & 0.000 & 0.012 & 0.000 & 0.012 & 0.000 & 0.004 & 0.000 & 0.004 & 0.000 & 0.004 & 0.000 & 0.017 & 0.000 & 0.017 & 0.000 & 0.017 & 0.000 \\
\hline InvComm & -0.033 & 0.188 & -0.033 & 0.188 & -0.033 & 0.188 & 0.004 & 0.237 & 0.004 & 0.237 & 0.004 & 0.237 & -0.029 & 0.252 & -0.029 & 0.252 & -0.029 & 0.252 \\
\hline DirFn & 0.015 & 0.000 & 0.015 & 0.000 & 0.015 & 0.000 & -0.001 & 0.000 & -0.001 & 0.000 & -0.001 & 0.000 & 0.014 & 0.000 & 0.014 & 0.000 & 0.014 & 0.000 \\
\hline FinDir & -0.236 & 0.000 & -0.236 & 0.000 & -0.236 & 0.000 & 0.023 & 0.020 & 0.023 & 0.020 & 0.023 & 0.020 & -0.213 & 0.001 & -0.213 & 0.001 & -0.213 & 0.001 \\
\hline IndDir & -0.146 & 0.000 & -0.146 & 0.000 & -0.146 & 0.000 & 0.073 & 0.000 & 0.073 & 0.000 & 0.073 & 0.000 & -0.074 & 0.000 & -0.074 & 0.000 & -0.074 & 0.000 \\
\hline \multicolumn{19}{|c|}{ Panel C: The effects of board structure on director ownership (Dir Own) } \\
\hline & \multicolumn{6}{|c|}{ Direct Effect } & \multicolumn{6}{|c|}{ Indirect Effect } & \multicolumn{6}{|c|}{ Total Effect } \\
\hline & \multicolumn{2}{|c|}{ Model 1} & \multicolumn{2}{|c|}{ Model 2} & \multicolumn{2}{|c|}{ Model 3} & \multicolumn{2}{|c|}{ Model 1} & \multicolumn{2}{|c|}{ Model 2} & \multicolumn{2}{|c|}{ Model 3} & \multicolumn{2}{|c|}{ Model 1} & Mod & el 2 & Mod & \\
\hline & Effect & P-val & Effect & P-val & Effect & P-val & Effect & P-val & Effect & P-val & Effect & P-val & Effect & P-val & Effect & P-val & Effect & P-val \\
\hline FundObj5 & 0.065 & 0.000 & 0.065 & 0.000 & 0.065 & 0.000 & & & & & & & 0.065 & 0.000 & 0.065 & 0.000 & 0.065 & 0.000 \\
\hline FundObj4 & 0.069 & 0.000 & 0.069 & 0.000 & 0.069 & 0.000 & & & & & & & 0.069 & 0.000 & 0.069 & 0.000 & 0.069 & 0.000 \\
\hline FundObj3 & 0.145 & 0.000 & 0.145 & 0.000 & 0.145 & 0.000 & & & & & & & 0.145 & 0.000 & 0.145 & 0.000 & 0.145 & 0.000 \\
\hline FundObj2 & 0.079 & 0.000 & 0.079 & 0.000 & 0.079 & 0.000 & & & & & & & 0.079 & 0.000 & 0.079 & 0.000 & 0.079 & 0.000 \\
\hline FundObj1 & 0.088 & 0.000 & 0.088 & 0.000 & 0.088 & 0.000 & & & & & & & 0.088 & 0.000 & 0.088 & 0.000 & 0.088 & 0.000 \\
\hline DirTn & -0.001 & 0.057 & -0.001 & 0.057 & -0.001 & 0.057 & & & & & & & -0.001 & 0.057 & -0.001 & 0.057 & -0.001 & 0.057 \\
\hline ProfDir & -0.262 & 0.000 & -0.262 & 0.000 & -0.262 & 0.000 & & & & & & & -0.262 & 0.000 & -0.262 & 0.000 & -0.262 & 0.000 \\
\hline AudComm & 0.052 & 0.249 & 0.052 & 0.249 & 0.052 & 0.249 & & & & & & & 0.052 & 0.249 & 0.052 & 0.249 & 0.052 & 0.249 \\
\hline BSize & 0.044 & 0.000 & 0.044 & 0.000 & 0.044 & 0.000 & & & & & & & 0.044 & 0.000 & 0.044 & 0.000 & 0.044 & 0.000 \\
\hline InvComm & 0.041 & 0.215 & 0.041 & 0.215 & 0.041 & 0.215 & & & & & & & 0.041 & 0.215 & 0.041 & 0.215 & 0.041 & 0.215 \\
\hline DirFn & -0.010 & 0.000 & -0.010 & 0.000 & -0.010 & 0.000 & & & & & & & -0.010 & 0.000 & -0.010 & 0.000 & -0.010 & 0.000 \\
\hline FinDir & 0.230 & 0.004 & 0.230 & 0.004 & 0.230 & 0.004 & & & & & & & 0.230 & 0.004 & 0.230 & 0.004 & 0.230 & 0.004 \\
\hline IndDir & 0.727 & 0.000 & 0.727 & 0.000 & 0.727 & 0.000 & & & & & & & 0.727 & 0.000 & 0.727 & 0.000 & 0.727 & 0.000 \\
\hline
\end{tabular}


Table 6. Structural equation model goodness of fit

\begin{tabular}{|c|c|c|c|c|}
\hline Measure & Model 1 & Model 2 & Model 3 & Description \\
\hline \multicolumn{5}{|c|}{ Likelihood ratio } \\
\hline chi2_ms & 6.555 & 5.683 & 5.683 & model vs. saturated \\
\hline $\mathrm{p}>\mathrm{chi} 2$ & 0.364 & 0.224 & 0.224 & \\
\hline chi2_bs & 3638 & 4150 & 3464 & baseline vs. saturated \\
\hline $\mathrm{p}>$ chi2 & 0 & 0 & 0 & \\
\hline \multicolumn{5}{|c|}{ Population error } \\
\hline RMSEA & 0.01 & 0.021 & 0.021 & Root mean squared error \\
\hline $90 \% \mathrm{CI}, \mathrm{lb}$ & 0 & 0 & 0 & Lower bound of confidence interval \\
\hline $90 \% \mathrm{CI}, \mathrm{ub}$ & 0.045 & 0.057 & 0.057 & Upper bound of confidence interval \\
\hline Pclose & 0.977 & 0.892 & 0.892 & Probability RMSEA $<=0.05$ \\
\hline \multicolumn{5}{|c|}{ Information criteria } \\
\hline $\mathrm{AIC}$ & -1904.8 & 14049 & 17040 & Akaike's information criterion \\
\hline $\mathrm{BIC}$ & -1658.1 & 14291 & 17282 & Bayesian information criterion \\
\hline \multicolumn{5}{|c|}{ Baseline comparison } \\
\hline CFI & 1 & 1 & 1 & Comparative fit index \\
\hline TLI & 0.999 & 0.995 & 0.994 & Tucker-Lewis index \\
\hline \multicolumn{5}{|c|}{ Size of residuals } \\
\hline SRMR & 0.002 & 0.002 & 0.002 & Standardized root mean squared residual \\
\hline $\mathrm{CD}$ & 0.979 & 0.988 & 0.975 & Coefficient of determination \\
\hline
\end{tabular}

Table 7. Structural equation model goodness of fit (R-squared)

\begin{tabular}{llllllllll}
\hline Measures & Perf1 & CGQ & DirOwn & Perf2 & CGQ & DirOwn & Perf3 & CGQ & DirOwn \\
\hline Fitted & 0.000 & 0.027 & 0.055 & 1.284 & 0.027 & 0.055 & 15.259 & 0.027 & 0.055 \\
Variance Predicted & 0.000 & 0.023 & 0.047 & 0.676 & 0.023 & 0.047 & 0.198 & 0.023 & 0.047 \\
Residual & 0.000 & 0.005 & 0.008 & 0.608 & 0.005 & 0.008 & 15.062 & 0.005 & 0.008 \\
R-squared & 0.182 & 0.827 & 0.857 & 0.526 & 0.827 & 0.857 & 0.013 & 0.827 & 0.857 \\
MC & 0.426 & 0.910 & 0.926 & 0.725 & 0.910 & 0.926 & 0.114 & 0.910 & 0.926 \\
MC-squared & 0.182 & 0.827 & 0.857 & 0.526 & 0.827 & 0.857 & 0.013 & 0.827 & 0.857 \\
\hline
\end{tabular}

Note. $\mathrm{MC}=$ correlation between dependent variables and its predictions.

\section{Copyrights}

Copyright for this article is retained by the author(s), with first publication rights granted to the journal.

This is an open-access article distributed under the terms and conditions of the Creative Commons Attribution license (http://creativecommons.org/licenses/by/4.0/). 